Article

\title{
Preparation and Characterization of Ni/ZrTiAlOx Catalyst via Sol-Gel and Impregnation Methods for Low Temperature Dry Reforming of Methane
}

\author{
Seol A Shin 1,2, Ali Alizadeh Eslami 1,3, Young Su Noh 1,2, Hyun-tae Song 1,3, \\ Hyun Dong Kim ${ }^{1,2} \mathbb{D}$, Nasim Ghaffari Saeidabad ${ }^{1,3}$ and Dong Ju Moon 1,2,3,*(D) \\ 1 Clean Energy Research Center, Korea Institute of Science and Technology (KIST), Hwarang-ro 14 gil 5, \\ Seongbuk-gu, Seoul 02792, Korea; cadiemsol@gmail.com (S.A.S.); alizadeh.ali@kist.re.kr (A.A.E.); \\ ysnoh@kist.re.kr (Y.S.N.); shtcwzz@kist.re.kr (H.-t.S.); hdkim99@kist.re.kr (H.D.K.); nasim@kist.re.kr (N.G.S.) \\ 2 Department of Chemical and Biological Engineering, Korea University, 145 Anam-ro, Seongbuk-gu, \\ Seoul 02841, Korea \\ 3 Division of Energy and Environment Technology, KIST School, Korea University of Science and Technology, \\ Seoul 02792, Korea \\ * Correspondence: djmoon@kist.re.kr; Tel.: +82-2-958-5867
}

Received: 5 October 2020; Accepted: 9 November 2020; Published: 17 November 2020

\begin{abstract}
Recently, the dry reforming of methane (DRM) has received much attention as a conversion technology of greenhouse gases. Ni-based catalysts supported on ternary metal oxide composite $\left(\mathrm{ZrTiAlO}_{x}\right)$ were prepared to improve the coke resistance properties in the DRM $\left(\mathrm{CH}_{4}: \mathrm{CO}_{2}=1\right)$ at low temperature. The $\mathrm{ZrTiAlO}_{x}$ supports with different ratios of $\mathrm{Zr} / \mathrm{Ti}$ were prepared through the modified Pechini sol-gel method, and then the Ni was impregnated on the synthesized support via the incipient wetness impregnation method. Considering the $\mathrm{Zr} / \mathrm{Ti}$ ratios, different catalytic activity and durability in the DRM were identified. The $\mathrm{Ni} / \mathrm{ZrTiAlO}{ }_{x}$ catalyst with $\mathrm{Zr} / \mathrm{Ti}$ of 2 exhibited enhanced coke inhibition property compared to the others at low temperature DRM for $50 \mathrm{~h}$. The catalysts with a high $\mathrm{Zr}$ /Ti ratio under the same condition were rapidly deactivated, while the catalyst with a low $\mathrm{Zr} / \mathrm{Ti}$ ratio showed deficient activity. It was found from temperature-programmed surface reactions (TPSR) and DRIFTS (Diffuse Reflectance Infrared Fourier Transform Spectroscopy) analysis that the addition of $\mathrm{Ti}$ has led in to higher catalytic stability at $\mathrm{Zr} / \mathrm{Ti}=2$, which could be as a result of oxygen vacancies generated by the ternary metal oxides. $\mathrm{Ni} / \mathrm{ZrTiAlO}{ }_{x}$ catalyst with ratio of $\mathrm{Zr} / \mathrm{Ti}=2$ showed high stability and good catalytic activity towards DRM for the production of syngas.
\end{abstract}

Keywords: Ni-based catalyst; dry reforming of methane; Strong Metal-Support Interaction (SMSI); Sol-Gel

\section{Introduction}

Climate change, air pollution, and global warming have become severe issues; thus, many efforts have been made to reduce greenhouse gases with main focus on $\mathrm{CO}_{2}$ and $\mathrm{CH}_{4}$. Among use and storage technologies, dry reforming of methane (DRM) has been considered a desirable technology for producing syngas and using greenhouse gases in recent decades [1-3]. Moreover, through the DRM, the synthesis gas ratio can be tuned for the Fischer-Tropsch processes to produce value-added chemicals such as dimethyl ether (DME) and methanol [4-7]. Ni-based catalysts have generally been reported to produce the syngas through various hydrocarbon-based feedstock [8,9]. Furthermore, Ni-based catalysts are considered to be a suitable catalyst for the reforming reaction due to the availability and abundance of $\mathrm{Ni}$ compared to Nobel metals. It was reported that nickel could be activated through the cleavage of $\mathrm{C}-\mathrm{H}, \mathrm{O}-\mathrm{H}$, and C-C bonds in the water-gas shift (WGS) reaction [10]. Even though the 
Ni-based catalyst showed promising active phases, it is prone to be deactivated by coke deposition during the reaction. In particular, the DRM has difficulty in commercialization due to its tendency to form carbon. It was reported that catalysts are deactivated quickly in the DRM because of the coke formation on the active sites [11]. Therefore, the design and development of an efficient and durable catalyst are necessary. Improvement of the catalyst basicity through the addition of alkaline earth metals to prevent the coke deposition in DRM $[12,13]$ is recommended. Furthermore, the preparation of nano-sized nickel particles has been also reported [14]. Many studies have studied the modification of catalyst support, which strongly influences the catalytic behavior and carbon deposition during the DRM $[13,15]$. Various supports such as $\mathrm{Al}_{2} \mathrm{O}_{3}, \mathrm{SiO}_{2}, \mathrm{ZrO}_{2}$, and $\mathrm{TiO}_{2}$ were investigated to improve catalytic activity and the coke resistance feature [16-20].

It was reported that the $\mathrm{TiO}_{2}$ as support in $\mathrm{Ni} / \mathrm{TiO}_{2}$ catalyst could influence to the deactivation of catalytic activity because of migrating $\mathrm{TiO} x$ over the nickel surface [21]. It has been indicated that $\mathrm{TiO} x$ species inhibit the coke deposition on the surface of $\mathrm{Ni} / \mathrm{TiO}_{2}$ catalyst, whereas large ensembles of metal atoms were geometrically abolished [22]. Also, based on density function theory (DFT) analysis, it is expected that the substituted the surface of Ti-substituted zirconia (111) could provide the oxygen vacancies near a solely isolated Ti dopant. The presence of Ti could significantly alter the chemical behavior in the catalyst surface. In other words, catalytic reducibility is improved by means of oxidation states related to the Ti centers [23]. $\mathrm{TiO}_{2}-\mathrm{ZrO}_{2}$, as mixed oxide composite support, exhibited good thermal stability and high mechanical strength with enhanced surface acidity. Moreover, Ti doped on the $\mathrm{ZrO}_{2}$ mainly amends the electronic structure by decreasing its optical absorption bandage. This occurs when the $\mathrm{Ti} 3 \mathrm{~d}$ band is formed in the $\mathrm{ZrO}_{2}$ bandgap.

$\mathrm{Ti}^{3+}$ centers are formed through transferring the internal electron from intrinsic defects (e.g., oxygen vacancies) [24]. Among various metal oxide supports, it was reported that the $\mathrm{TiO}_{2}-\mathrm{ZrO}_{2}$ composite metal oxide had shown identical features as catalyst supports. The addition of $\mathrm{ZrO}_{2}$ does not affect the main structural characteristics; however, it boosts the catalyst [25].

In our previous research, a series of $\mathrm{Ni} / \mathrm{ZrO}_{2}-\mathrm{Al}_{2} \mathrm{O}_{3}$ catalysts were synthesized successfully for use in the DRM [26]. To our knowledge, there are few studies on mixed metal oxide support $\mathrm{TiO}_{2}-\mathrm{ZrO}_{2}$, and there has been no report about ternary support composition $(\mathrm{Zr}, \mathrm{Ti}, \mathrm{Al})$ in the DRM. In this work, the Ni-based catalyst supported on $\mathrm{ZrO}_{2}-\mathrm{Al}_{2} \mathrm{O}_{3}-\mathrm{TiO}_{2}$ was investigated to develop a high-performance catalyst with sufficient coke resistance for the DRM process at low temperatures. The optimization of proper composition for the support material in Ni-based catalyst is significant to application in the DRM.

\section{Results and Discussion}

\subsection{Physico-Chemical Analysis}

Table 1 lists the physical properties of $\mathrm{Ni} / \mathrm{ZrTiAlO}_{x}$ catalysts and the particle sizes calculated from XRD patterns. Greater pore diameter was attributed to the lower $\mathrm{Zr}$ /Ti ratio. The addition of $\mathrm{TiO}_{2}$ in the support led to the expansion of the pore size range [27]. Moreover, the lower $\mathrm{Zr} / \mathrm{Ti}$ ratio displays higher surface area.

Figure 1 exhibits the X-ray patterns of $\mathrm{Ni} / \mathrm{ZrTiAlO}_{x}$ catalyst with varied molar ratios of $\mathrm{Zr}$ to $\mathrm{Ti}$. The synthesized catalysts were calcined at $800{ }^{\circ} \mathrm{C}$ and the broad XRD peaks indicated a fine crystalline size. $\mathrm{NiAl}_{2} \mathrm{O}_{4}$ spinel structure (JCPDS No. 10-0339) and NiO (JCPDS No. 47-1049) were detected in all the synthesized catalysts. With increasing $\mathrm{ZrO}_{2}$ in the ternary support mixture $\left(\mathrm{ZrTiAlO}_{x}\right)$, the crystalline size of the nickel oxide showed a decline trend. Additionally, by increasing the $\mathrm{Zr}$ contents in $\mathrm{Zr} / \mathrm{Ti}$ molar ratio, it was found that the peak of tetragonal $\mathrm{ZrO}_{2}\left(\mathrm{t}-\mathrm{ZrO}_{2}\right)$ (JCPDS No. 80-0965) showed higher intensity than low $\mathrm{Zr} / \mathrm{Ti}$ molar ratios. It meant that the crystalline size of $\mathrm{t}-\mathrm{ZrO}_{2}$ becomes larger with higher $\mathrm{Zr} / \mathrm{Ti}$ molar ratio of the catalysts. In case of the NTA catalyst, the main peaks of $\mathrm{TiO}_{2}$ were detected as anatase (JCPDS No. 21-1272) and rutile (JCPDS No. 21-1276). The peak of $\mathrm{NiTiO}_{3}$ was also confirmed in the NTA catalyst (JCPDS No. 033-0960). It was found that the prepared catalysts 
have similar structures to each other from the XRD patterns, which means that the supports were formed as physical mixed structure.

Table 1. Physicochemical properties of prepared catalysts $\left(\mathrm{Ni} / \mathrm{ZrTiAlO}_{x}\right)$.

\begin{tabular}{|c|c|c|c|c|c|c|c|c|}
\hline \multirow[t]{2}{*}{$\begin{array}{c}\text { Catalysts } \\
\text { Code }\end{array}$} & \multicolumn{3}{|c|}{$\begin{array}{l}\text { Support Component } \\
\text { Molar Ratio }\end{array}$} & \multirow[t]{2}{*}{$\begin{array}{l}\text { Zr/Ti Molar } \\
\quad \text { Ratio }\end{array}$} & \multirow{2}{*}{$\begin{array}{c}\text { Surface } \\
\text { Area } \\
\left(\mathrm{m}^{2} / \mathrm{g}\right)\end{array}$} & \multirow{2}{*}{$\begin{array}{c}\text { Pore } \\
\text { Volume } 1 \\
\left(\mathrm{~cm}^{3} / \mathrm{g}\right)\end{array}$} & \multirow{2}{*}{$\begin{array}{l}\text { Average Pore } \\
\text { Diameter } \\
(\mathrm{nm})\end{array}$} & \multirow{2}{*}{$\begin{array}{l}\text { NiO Size } \\
\quad(n m)\end{array}$} \\
\hline & $\mathrm{Ti}$ & $\mathrm{Zr}$ & $\mathrm{Al}$ & & & & & \\
\hline NTA & 1 & - & 3 & - & 4.9 & 0.028 & 23.5 & 8.9 \\
\hline NZTA (1) & 0.5 & 0.5 & 3 & 1 & 20.6 & 0.065 & 12.7 & 10.7 \\
\hline NZTA (2) & 0.3 & 0.7 & 3 & 2 & 7.5 & 0.022 & 12.3 & 10.0 \\
\hline NZTA (4) & 0.2 & 0.8 & 3 & 4 & 6.9 & 0.060 & 7.9 & 7.4 \\
\hline NZA & - & 1 & 3 & - & 17.3 & 0.037 & 8.5 & 15.2 \\
\hline
\end{tabular}

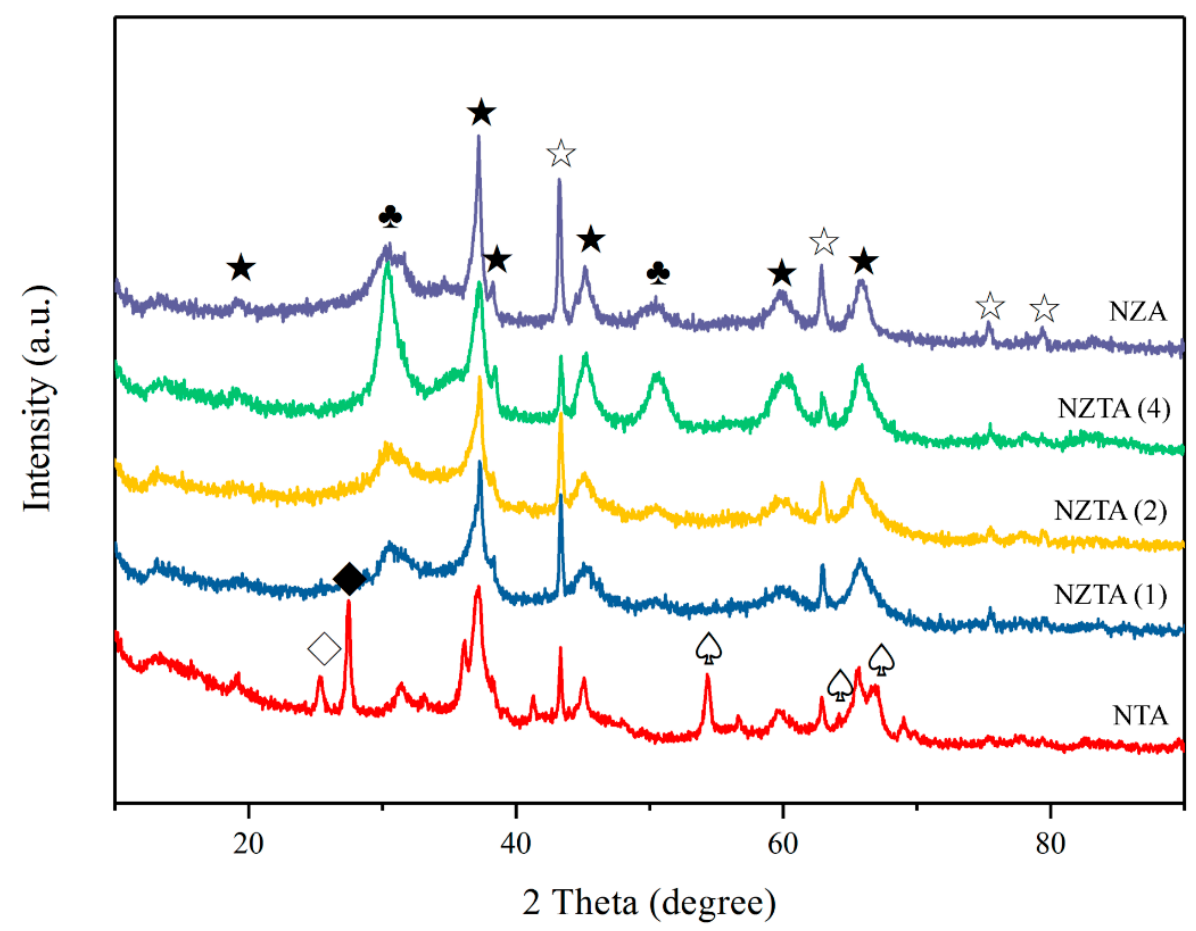

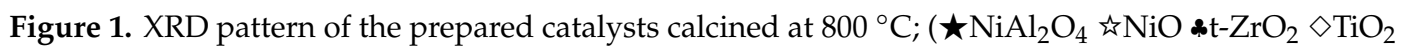
anatase $\mathrm{TiO}_{2}$ rutile $\stackrel{\mathrm{Q}}{\mathrm{NiTiO}}{ }_{3}$ ).

The reducibility of $\mathrm{Ni} / \mathrm{ZrTiAlO}{ }_{x}$ catalysts was investigated to understand the redox properties and the hydrogen-temperature-programmed reduction $\left(\mathrm{H}_{2}\right.$-TPR) profiles are summarized in Figure 2 . The TPR profiles of the catalyst which include $\mathrm{ZrO}_{2}$ consist of three peaks. It was expected that the peak at $\mathrm{T}=400{ }^{\circ} \mathrm{C}$ is related to the reduction of $\mathrm{NiO}$. The peaks at $\mathrm{T}=470$ and $800{ }^{\circ} \mathrm{C}$ are credited to the reduction of bulk $\mathrm{NiO}$ particles involved with support and the $\mathrm{NiAl}_{2} \mathrm{O}_{4}$ spinel structure, accordingly. Meanwhile, the TPR profile for the NTA catalyst indicated peak at $650{ }^{\circ} \mathrm{C}$, which is related to the reduction of $\mathrm{NiTiO}_{3}$ [28]. Peaks in the NZTA (2) catalyst were shifted to a higher temperature compared to the other synthesized catalysts. This phenomenon could resemble the strong metal-support interaction (SMSI) effect with Ni and the support. Furthermore, the peak for the $\mathrm{NiAl}_{2} \mathrm{O}_{4}$ with existing $\mathrm{TiO}_{2}$ on support shifted lower temperature compared to NZA catalyst. It could be interpreted that the incorporation of $\mathrm{TiO}_{2}$ with $\mathrm{ZrO}_{2}-\mathrm{Al}_{2} \mathrm{O}_{3}$ weakens the interaction between $\mathrm{NiO}$ and $\mathrm{Al}_{2} \mathrm{O}_{3}$. It was previously confirmed that increasing $\mathrm{TiO}_{2}$ could cause a decrease in the quantity of spinel structures [18,29]. 


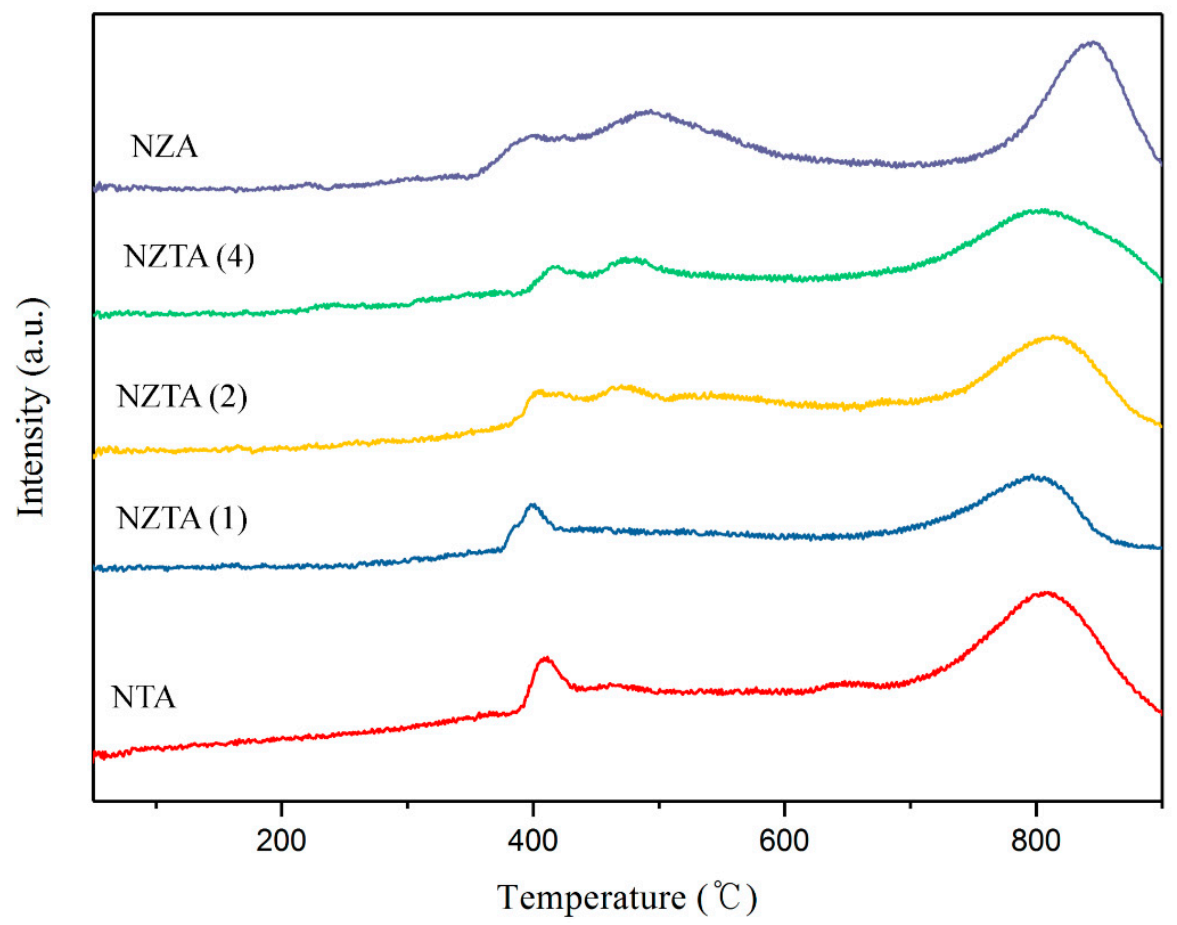

Figure 2. $\mathrm{H}_{2}$-TPR profiles of the prepared catalysts.

\subsubsection{Temperature-Programmed Surface Reaction (TPSR)}

Figure 3 depicts the TPSR profiles for the synthesized catalysts with various $\mathrm{Zr} / \mathrm{Ti}$ ratio. The composition of product was continuously analyzed by mass spectrometry. It was found that as the Ti content in the catalyst increases, the surface reaction initiated at a high temperature. It was found that the initiation temperature of TPSR over the synthesized catalyst increased from 400 to $480{ }^{\circ} \mathrm{C}$ under the tested conditions and the order of the initiation temperature for the reaction on the surface of catalyst are as follow: NTA $>$ NZTA (1) > NZTA (2) > NZTA (4) > NZA. It was reported that the rate determining step which is the breaking of the $\mathrm{C}-\mathrm{H}$ bond from $\mathrm{CH}_{4}$ to $\mathrm{CH}_{\mathrm{x}}$ surface species occurs over nickel active sites [10]. XRD and TPR results confirmed that in the lower ratios of $\mathrm{Zr} / \mathrm{Ti}=0,1$, and 2, strong interaction between metal and support was observed. Therefore, decomposition rate of $\mathrm{CH}_{4}$ is slowed down and consequently the starting temperature for catalysts with low $\mathrm{Zr} / \mathrm{Ti}$ ratio is higher.

The dehydrogenation of methane ensues on $\mathrm{Ni}$, and $\mathrm{CO}_{2}$ adsorbs as carbonate on the support [30]. To better understand the cracking of $\mathrm{CH}_{4}$, the temperature-programmed dehydrogenation of methane was performed over NZA, NZTA (2) and NTA reduced catalysts (Figure 4). It was found that as an addition of Ti into $\mathrm{ZrO}_{2}-\mathrm{Al}_{2} \mathrm{O}_{3}$ support system, the reaction temperature is observed at a higher temperature than NZA. This result can translate that the addition of Ti as NTA and NZTA (2) could interrupt the formation of the coke deposition, which cause the deactivation of the catalyst, and the coke resistance increases as follows: NZTA $(2)\left(612{ }^{\circ} \mathrm{C}\right)>\operatorname{NTA}\left(602{ }^{\circ} \mathrm{C}\right)>\mathrm{NZA}\left(526^{\circ} \mathrm{C}\right)$. 

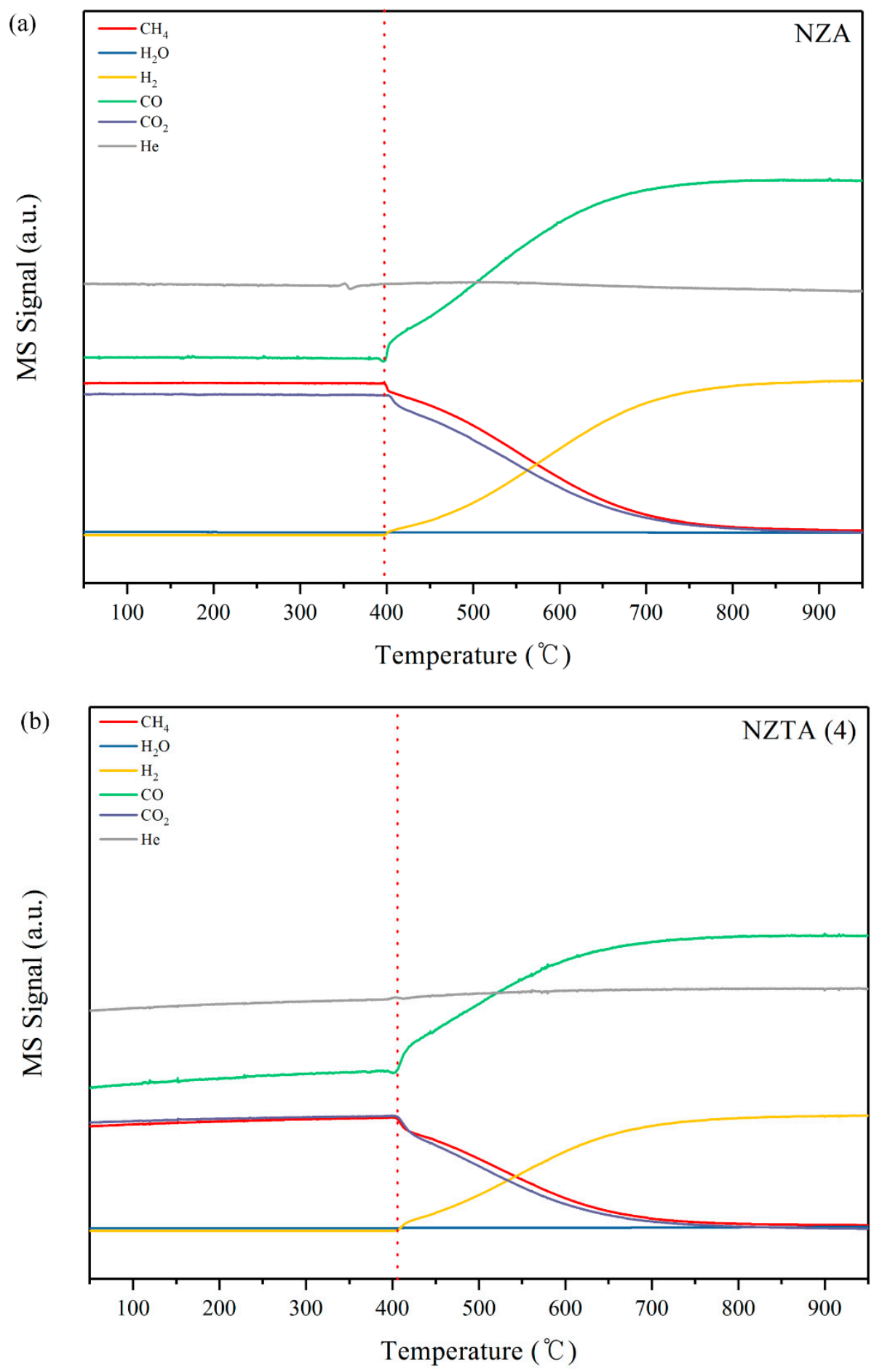

Figure 3. Cont. 

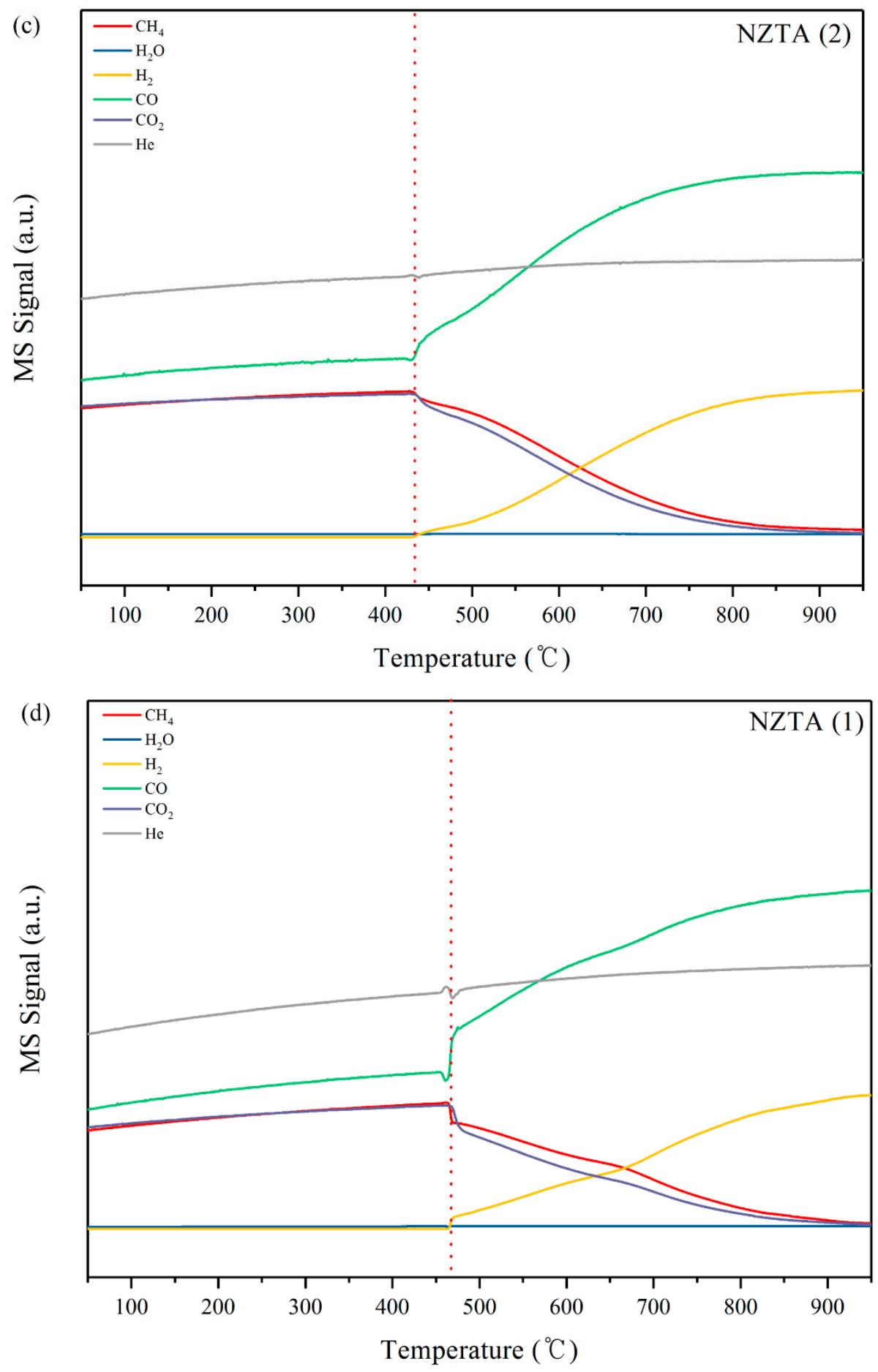

Figure 3. Cont. 


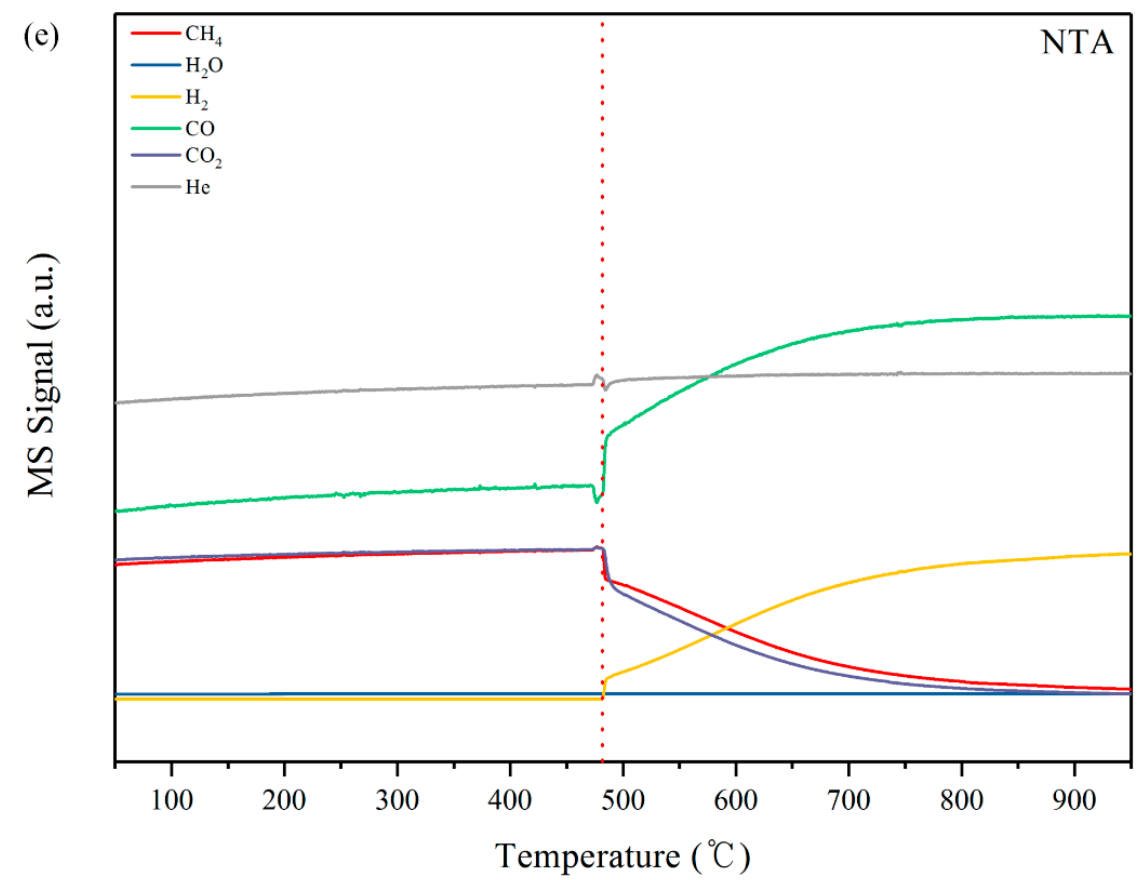

Figure 3. Temperature-programmed surface reaction profiles over the prepared catalysts with different $\mathrm{Zr}$ /Ti ratio in the dry reforming of methane (a) NZA, (b) NZTA (4), (c) NZTA (2), (d) NZTA (1), (e) NTA; Reaction condition: Total flow: $50 \mathrm{~cm}^{3} / \mathrm{min}$; feed composition: $\mathrm{CH}_{4}: \mathrm{CO}_{2}: \mathrm{He}=1: 1: 8$.

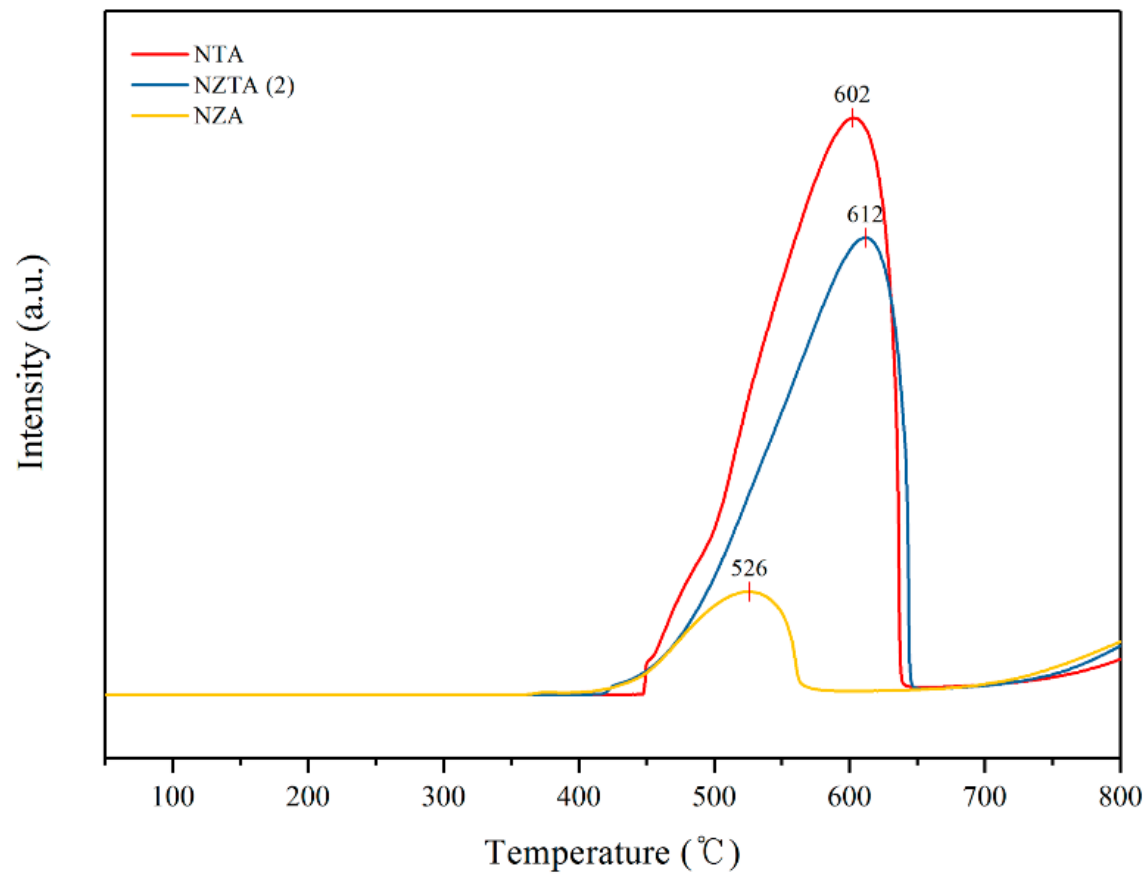

Figure 4. Temperature-programmed decomposition of methane over the reduced NZA, NZTA (2), and NTA catalysts. Reaction conditions: Total flow: $30 \mathrm{~cm}^{3} / \mathrm{min}$; feed composition: $\mathrm{CH}_{4}=1$.

\subsubsection{In Situ DRIFT Study on Dry Reforming of Methane}

Figure 5 shows the DRIFT spectra which was collected at the steady-state condition using reduced catalysts. The DRIFTS spectrum of the synthesized indicates a broad peak between $1468-1588 \mathrm{~cm}^{-1}$ which is attributed to the carbonate components on the support. The peak around $3500-3750 \mathrm{~cm}^{-1}$ is related to the $\mathrm{O}-\mathrm{H}$ stretching mode of hydroxyls in the support. Moreover, in this analysis only the 
gaseous phase contribution such as $\mathrm{CO}_{2}\left(2357-2310 \mathrm{~cm}^{-1}\right), \mathrm{CH}_{4}\left(3016 \mathrm{~cm}^{-1}\right)$, and $\mathrm{CO}$ bands $(2166$ and $2116 \mathrm{~cm}^{-1}$ ) were observed. The lack of linearly adsorbed carbon monoxide on the Ni active sites reveals it can be desorbed prior to more decomposition. Hence, this observation confirms that the coke deposition from Boudouard mechanism could be decreased through lowering the $\mathrm{CO}$ adsorption on Ni active sites. The peaks attributed to carbonate in NZTA (2), NZTA (1), NTA catalysts were much broad and weaker compared to the NZA, and NZTA (4). This phenomenon offers that there are more oxygen vacancies in catalysts with lower $\mathrm{Zr} / \mathrm{Ti}$ ratio, which also influences the absorption of carbon dioxide [31].

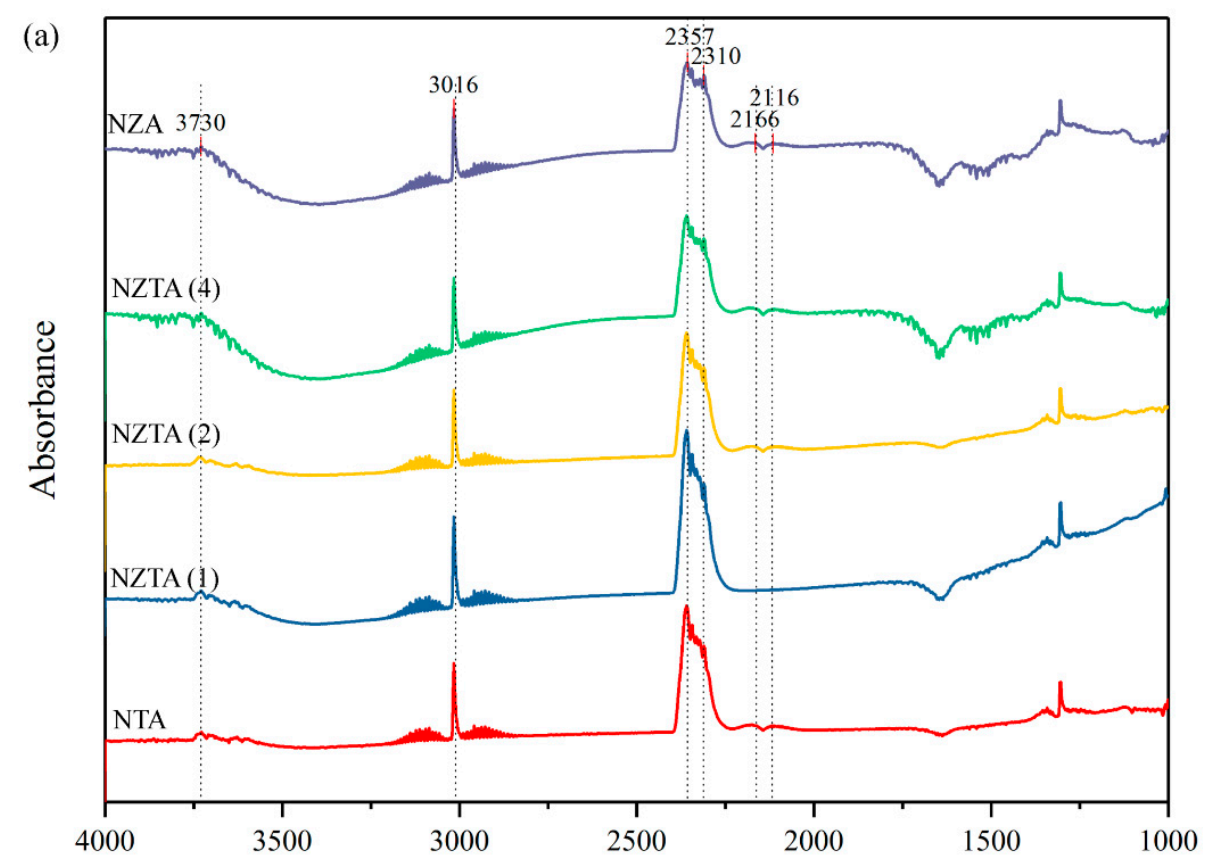

Wavenumber $\left(\mathrm{cm}^{-1}\right)$

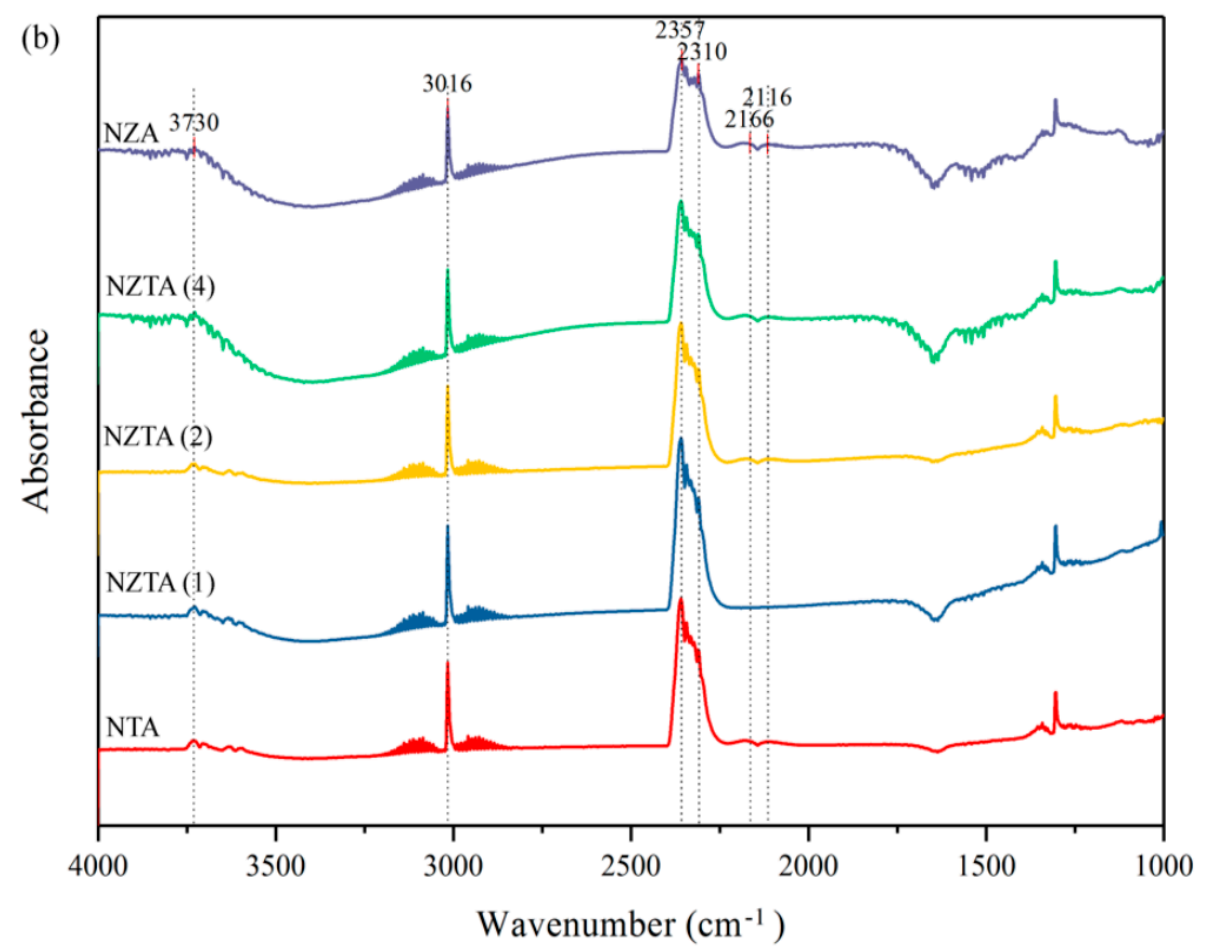

Figure 5. Cont. 
(c)

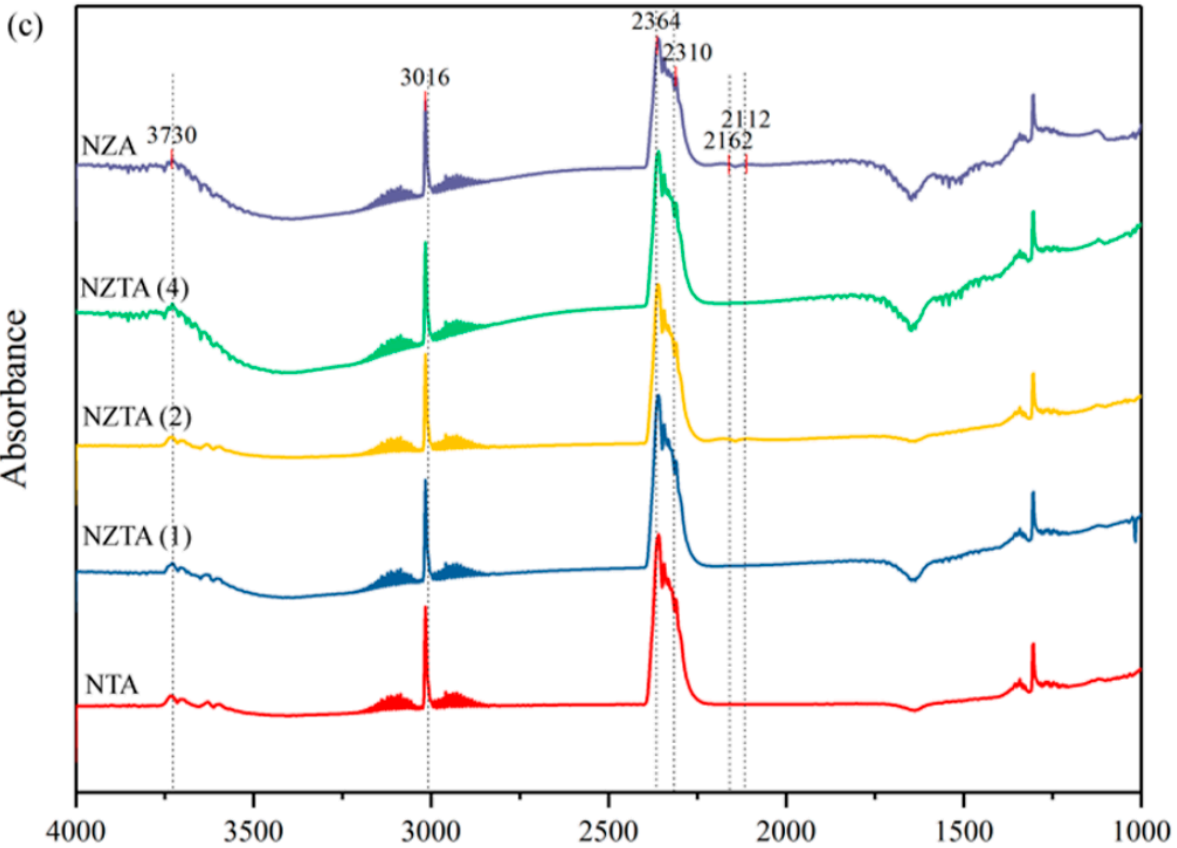

Wavenumber $\left(\mathrm{cm}^{-1}\right)$

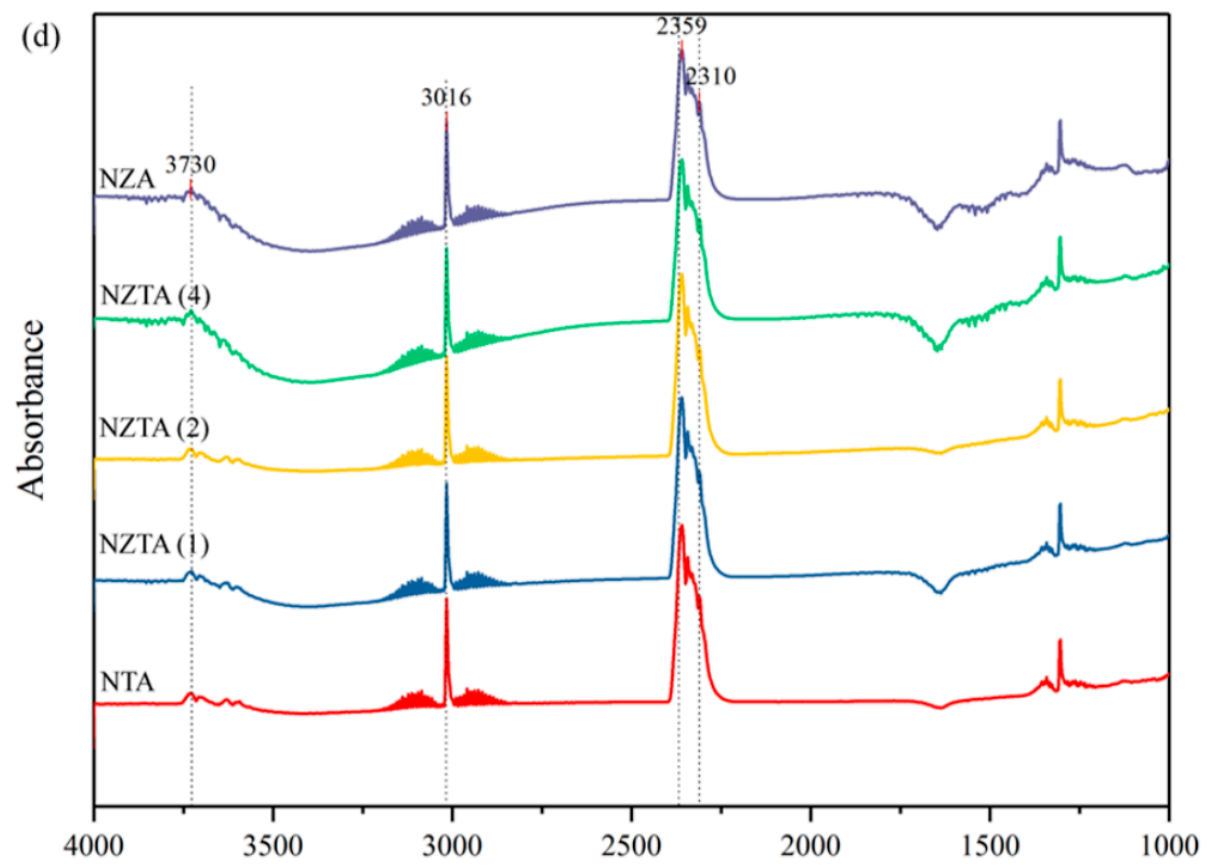

Wavenumber $\left(\mathrm{cm}^{-1}\right)$

Figure 5. Cont. 


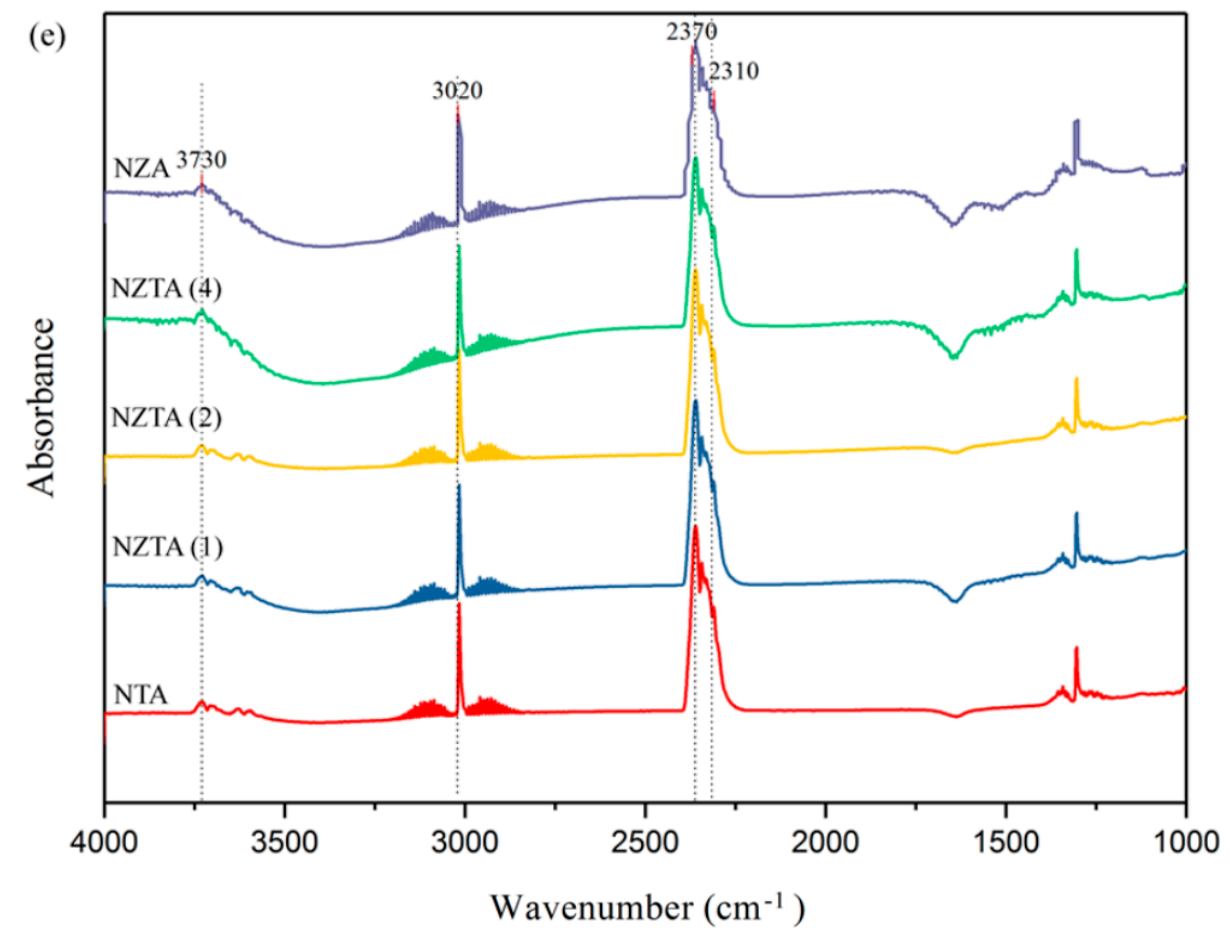

Figure 5. In situ DRIFT spectra of $\mathrm{CH}_{4}-\mathrm{CO}_{2}$ adsorbed over the prepared catalysts at different reaction temperature over reduced catalysts (a) $600{ }^{\circ} \mathrm{C}$, (b) $550{ }^{\circ} \mathrm{C}$, (c) $500{ }^{\circ} \mathrm{C}$, (d) $450{ }^{\circ} \mathrm{C}$, (e) $400{ }^{\circ} \mathrm{C}$.

The oxygenated components from the support could play a key role in the reaction mechanism for gasification of the deposited carbons [31]. The sequential $\mathrm{CH}_{4} / \mathrm{CO}_{2} / \mathrm{CH}_{4}$ DRIFTS analysis were carried out at $500{ }^{\circ} \mathrm{C}$ to investigate the effect of support on the formation intermediate species. Figure 6 illustrates the results of in situ DRIFT using $\mathrm{CH}_{4} / \mathrm{CO}_{2} / \mathrm{CH}_{4}$. It has to be noticed that in addition to methane, peaks related to the carbon dioxide were detected at $2360 \mathrm{~cm}^{-1}$ which indicates that the lattice oxygen from the support is prone to oxidize the coke species deposited on the catalyst. This capability of ZTA catalyst to oxidize $\mathrm{CH}_{4}$ in the absence of $\mathrm{CO}_{2}$ is important as a feature for catalysts with high resistance of coke formation. The coke resistance of NZTA (2) catalyst depicted in Figure 4 could be due to the lattice oxygen which was also confirmed by DRIFTS in Figure 6. Due to the lack of linearly adsorbed peaks related to the carbon monoxide on the NZTA (2) catalyst and the oxidation capability of the deposited cokes, it could be assumed that the DRM over NZTA (2) catalyst follows a bi-functional redox mechanism. Herein, the lattice oxygen acts actively in the coke gasification. Somehow, $\mathrm{CH}_{4}$ would follow dissociative adsorption on nickel to initially generate $\mathrm{C}-\mathrm{Ni}$. Then by the aid of oxygen sites $O_{x}$, the coke will be decomposed and consequently $C O$ and an oxygen vacancy $O_{x-1}$ will be released. It is expected that the oxygen vacancies could act as the active sites with capability of adsorption for carbon dioxide. With bearing this assumption in mind, the dissociation of the $\mathrm{CO}_{2}$ could occur on the supports and not the Ni sites for NZTA (2) catalyst. Therefore, an Ni-CO component would not be formed through the dissociation of carbon dioxide in case of NZTA (2) catalyst. 

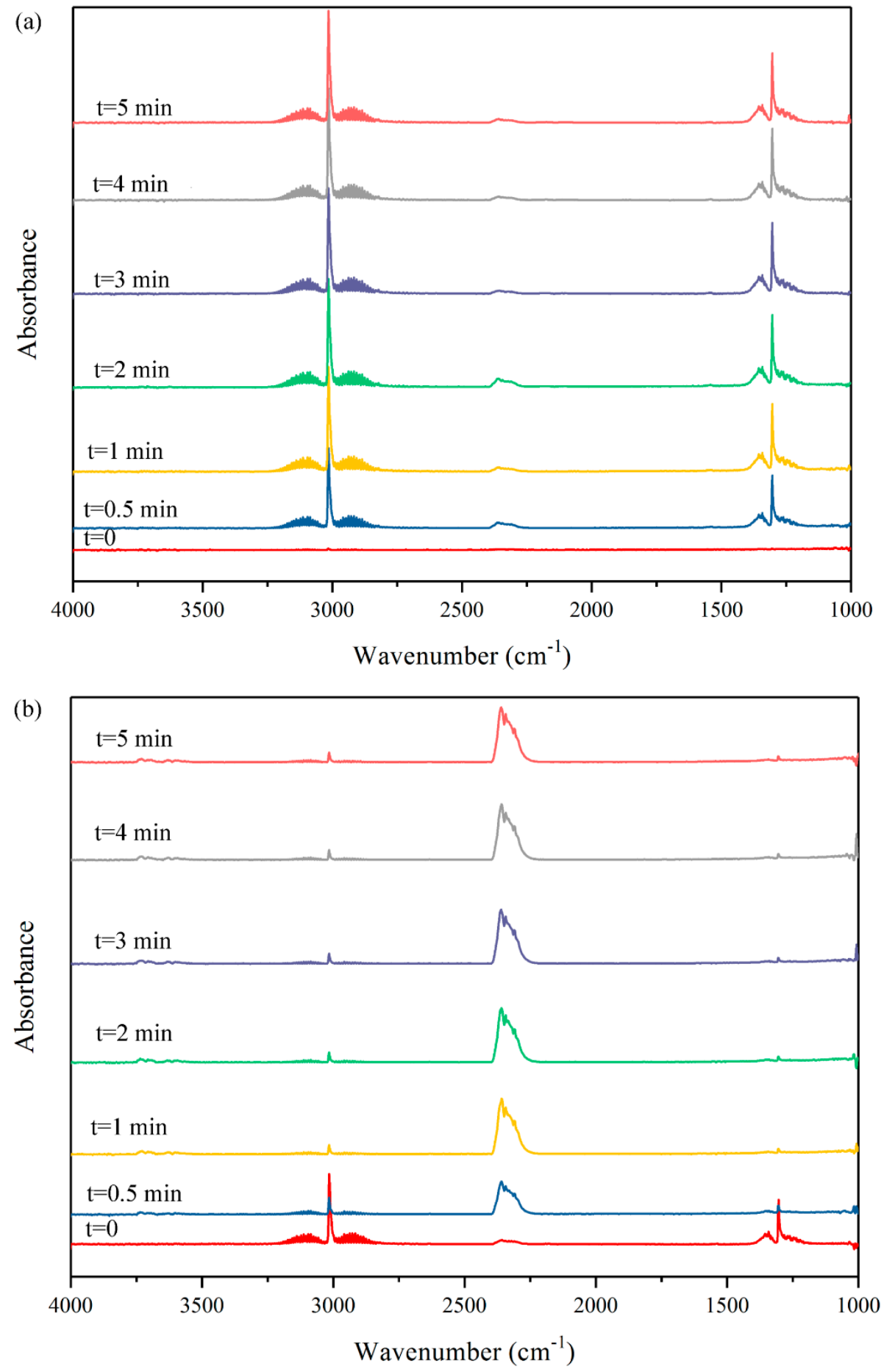

Figure 6. Cont. 


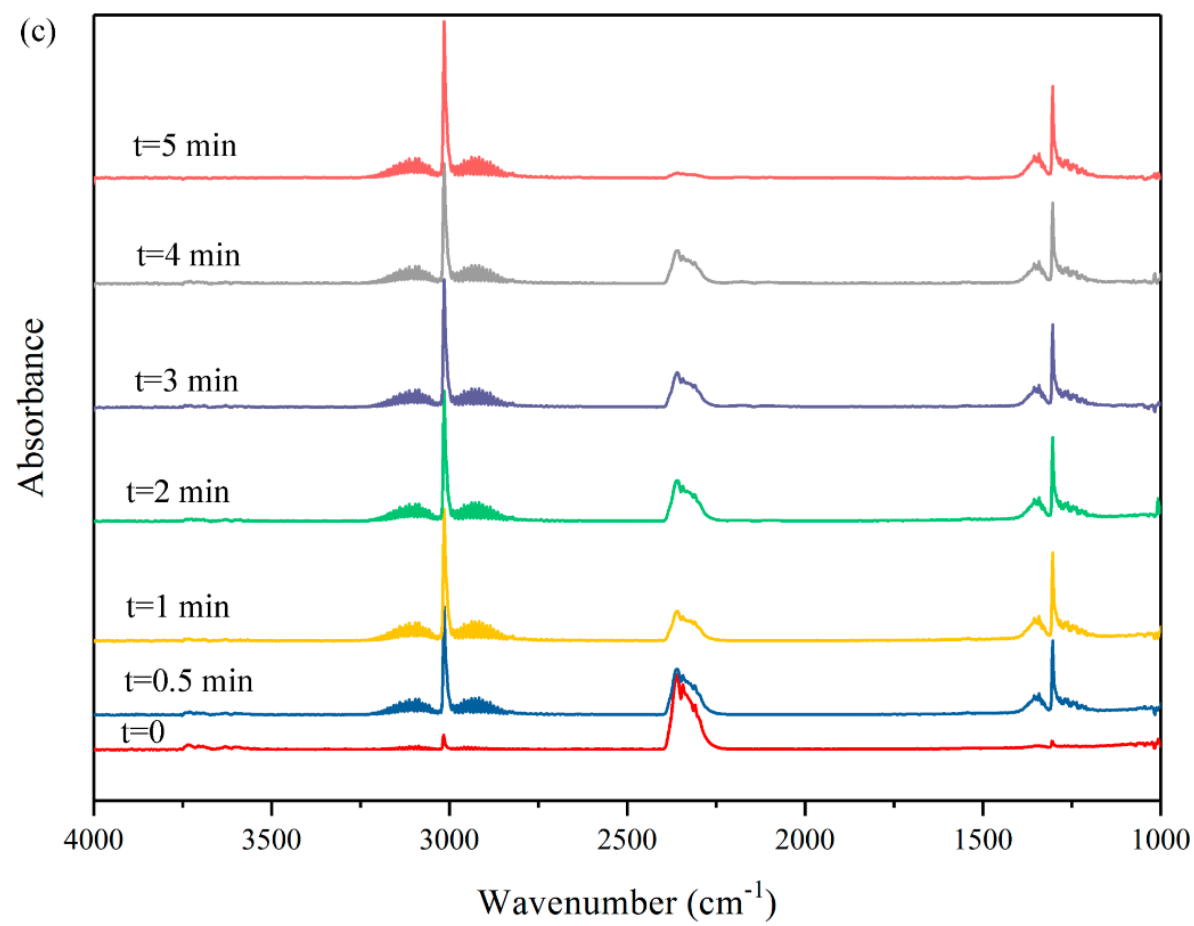

Figure 6. DRIFTS spectra obtained over the reduced NZTA (2) in the sequential DRIFTS experiment of $\mathrm{CH}_{4}-\mathrm{CO}_{2}-\mathrm{CH}_{4}$ at $500{ }^{\circ} \mathrm{C}$ (a) first $\mathrm{CH}_{4}$ inject (b) subsequent $\mathrm{CO}_{2}$ inject (c) subsequent $\mathrm{CH}_{4}$ inject.

\subsection{Catalyst Evaluation in the Dry Reforming of Methane}

\subsubsection{Dry Reforming over the Prepared Catalyst}

Based on the results for the catalytic performance tests, it was observed that according to different $\mathrm{Zr} / \mathrm{Ti}$ contents in support the catalytic performance and $\mathrm{H}_{2} / \mathrm{CO}$ ratio each on the time on stream (TOS) are shown in Figure 7. It was confirmed that the higher the $\mathrm{Zr}$ /Ti ratio of the catalysts would also led into the higher the activity, but at the moment catalytic stability could be also low and catalyst deactivation occurs through the coke deposition very quickly.

To study the effect of various ratios of $\mathrm{Zr} / \mathrm{Ti}$ towards the coke deposition, TGA, and TPH analysis were performed. Figure 8 shows the TPH profiles for the used the spent catalysts which reacted for $5 \mathrm{~h}$ in the DRM. The results confirmed the presence of two main types of carbonaceous components on the catalysts. The peak located around $\mathrm{T}=200-300{ }^{\circ} \mathrm{C}$ is related to $\mathrm{C}_{\alpha}$ which could be due to the hydrogenation of adsorbed carbon dioxide on the support [32]. The other peak which was detected around $\mathrm{T}=600^{\circ} \mathrm{C}$ could be related to $\mathrm{C}_{\beta}$ which is for hydrogenation of cokes as whisker-type filamentous carbon [33]. It was concluded that as the $\mathrm{Zr}$ contents in the support increased, the $\mathrm{C}_{\beta}$ intensity became greater.

Figure 9 shows the TGA profiles of the spent catalysts reacted for $5 \mathrm{~h}$ in the DMR. The trend for the amount of deposited coke detected by TGA was following similar order in TPH analysis. The weight change was primary was indicated at $\mathrm{T}=400-500{ }^{\circ} \mathrm{C}$, which could be related to the oxidation of nickel to nickel oxide. Additionally, NZA and NZTA (4) in Figure 9 is also related to the presence of $\mathrm{C}_{\alpha}$ which would be a stronger weight loss at lower temperature. The coke oxidation occurred at $\mathrm{T}>500{ }^{\circ} \mathrm{C}$. This result confirms that increasing Ti content in the support could lower the rate of $\mathrm{CH}_{4}$ dehydrogenation. This could be explained by the SMSI effect between Ni and the ternary support. Therefore, it was observed that synthesized catalysts with lower $\mathrm{Zr} / \mathrm{Ti}$ ratio showed lower coke deposition during the DRM. Furthermore, based on the DRIFT and TPSR results (shown in Figures 3 and 5) it was concluded that oxygen vacancies were presented more in the catalysts with 
higher Ti content. It is important to notice that the oxygen lattice could drastically enhance the coke gasification during the reaction.

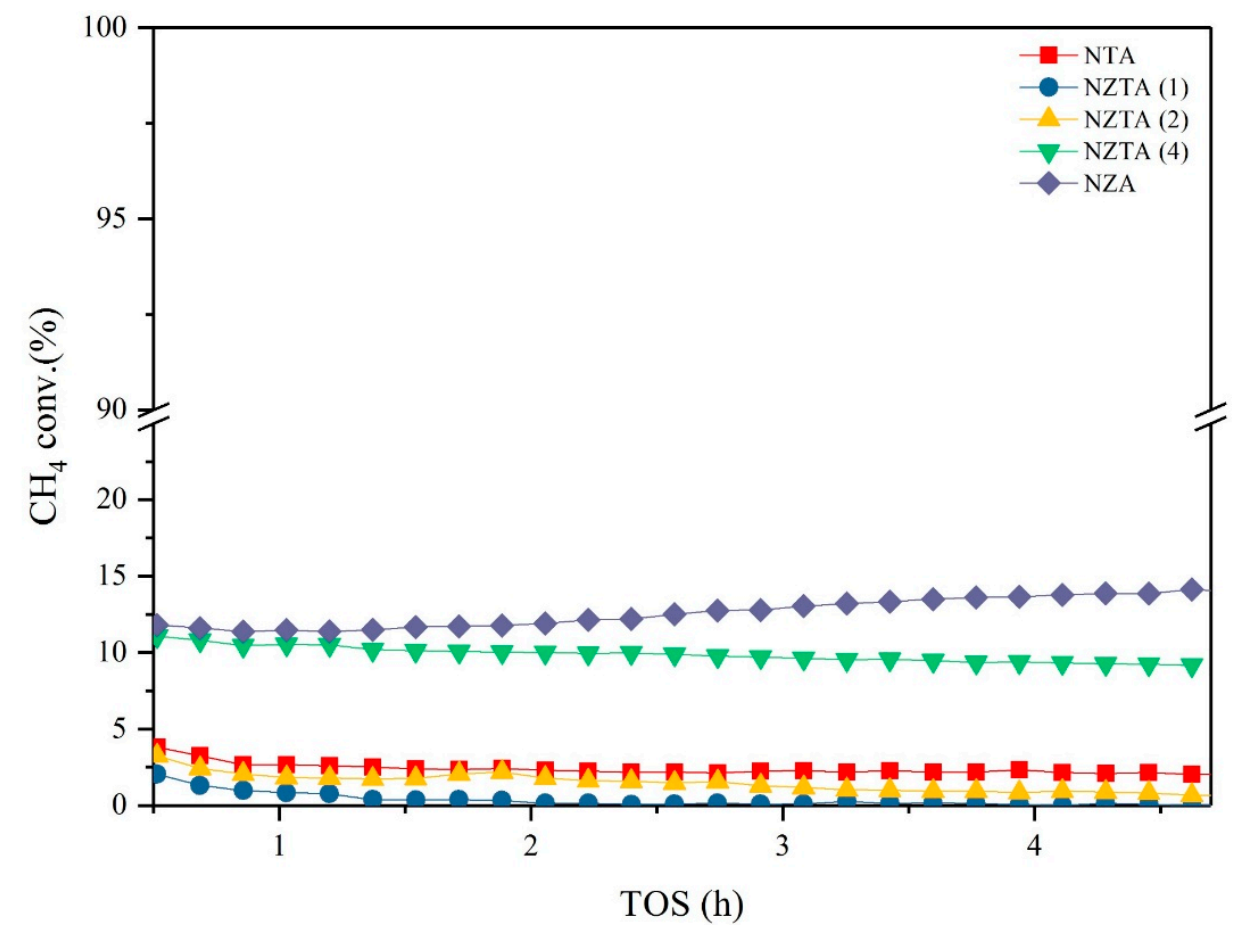

(a)

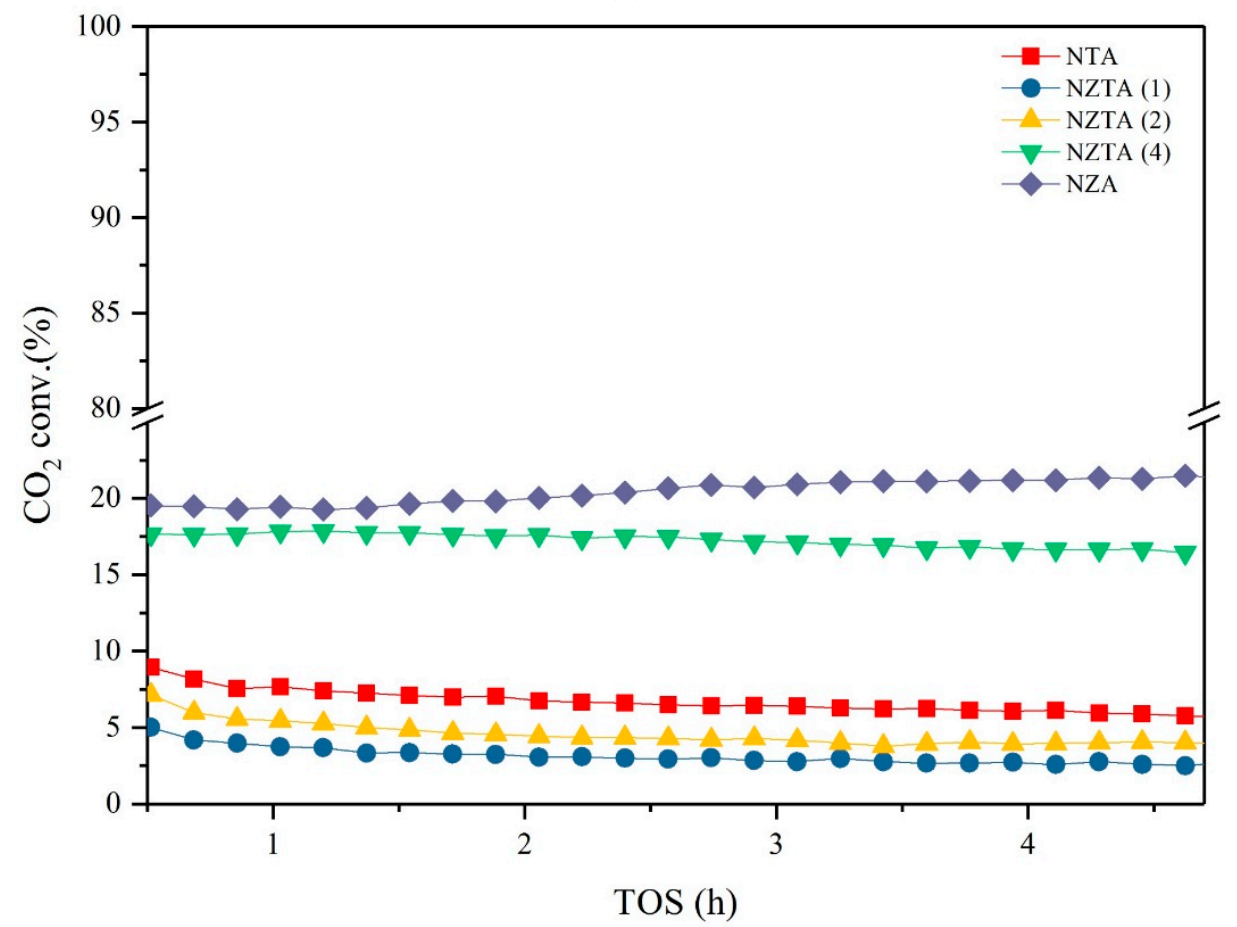

(b)

Figure 7. Catalytic performance of the prepared catalysts with different $\mathrm{Zr} / \mathrm{Ti}$ ratio under the tested conditions for $5 \mathrm{~h}(\mathbf{a}) \mathrm{CH}_{4}$ conversion (\%) (b) $\mathrm{CO}_{2}$ conversion (\%). 


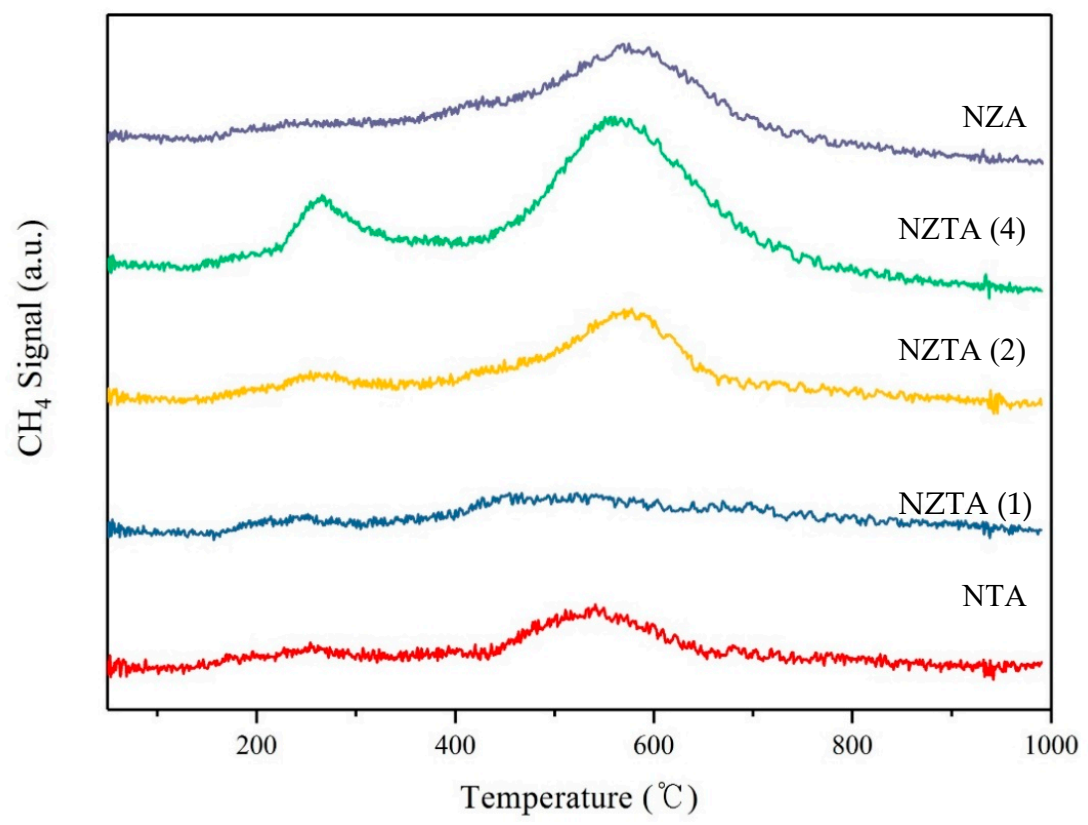

Figure 8. The temperature-programmed hydrogenation (TPH) profiles of the spend catalysts for $5 \mathrm{~h}$.

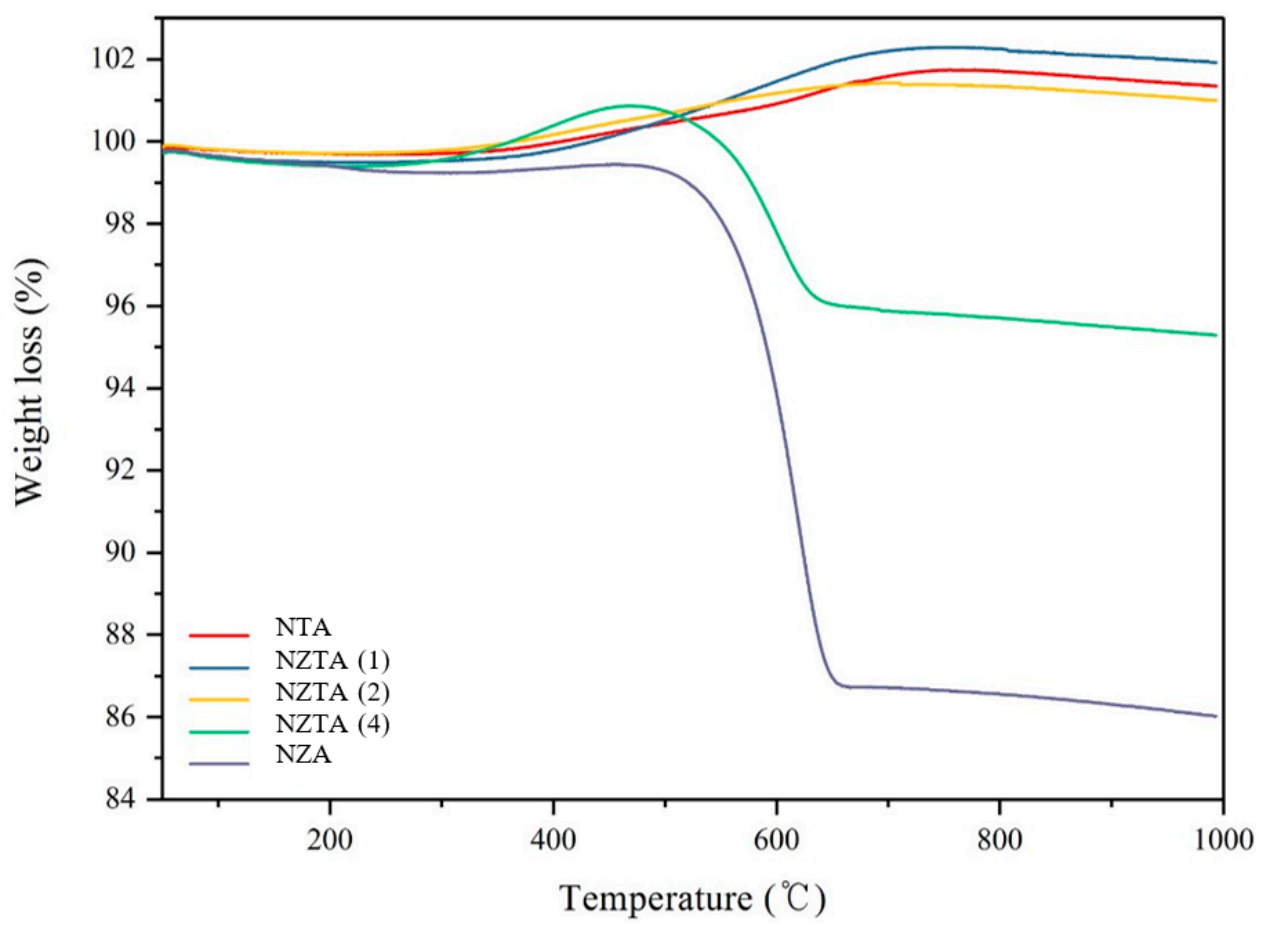

Figure 9. The TGA profiles of the spend catalysts reacted for $5 \mathrm{~h}$.

\subsubsection{Long-Term Stability of Catalyst}

Catalytic stability tests were performed for two catalysts: NZTA (2) and NTA. The DRM reaction was carried out for $50 \mathrm{~h}$. The result is shown in Figure 10. Each conversion curve was compared by linear fitting analysis. Compared with the methane conversion of NTA and NZTA (2), the time of achieved zero conversion of NTZA (2) is $79 \mathrm{~h}$ and NTA is $64 \mathrm{~h}$.

It is considered that NTZA (2) has better stability than NTA by about $19 \%$. Additionally, NZTA (2) catalyst explicitly exhibited higher coke resistance based on the TGA results shown in Figure 11. 


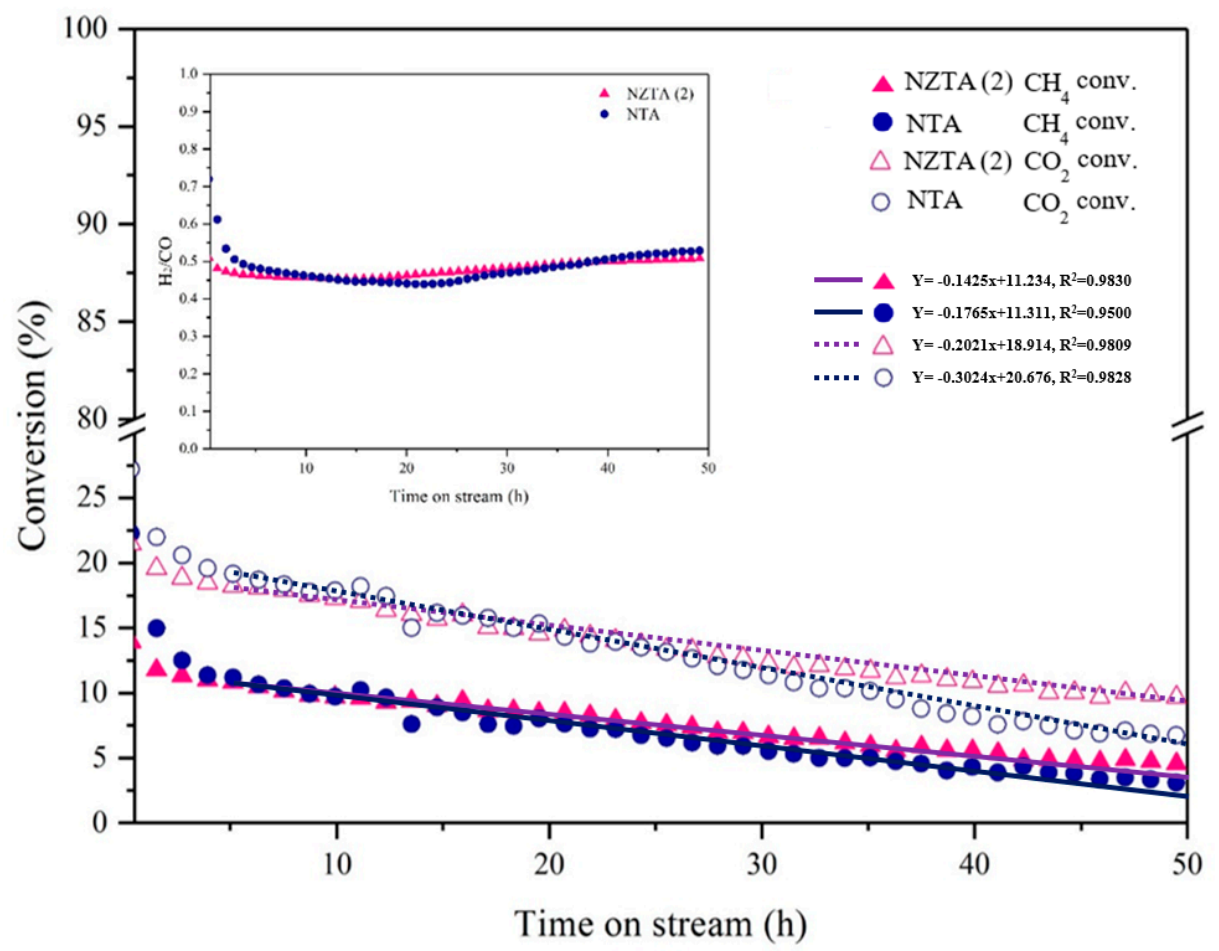

Figure 10. Catalytic stability of the prepared catalysts (NZTA (2) and NTA) reacted for $50 \mathrm{~h}$.

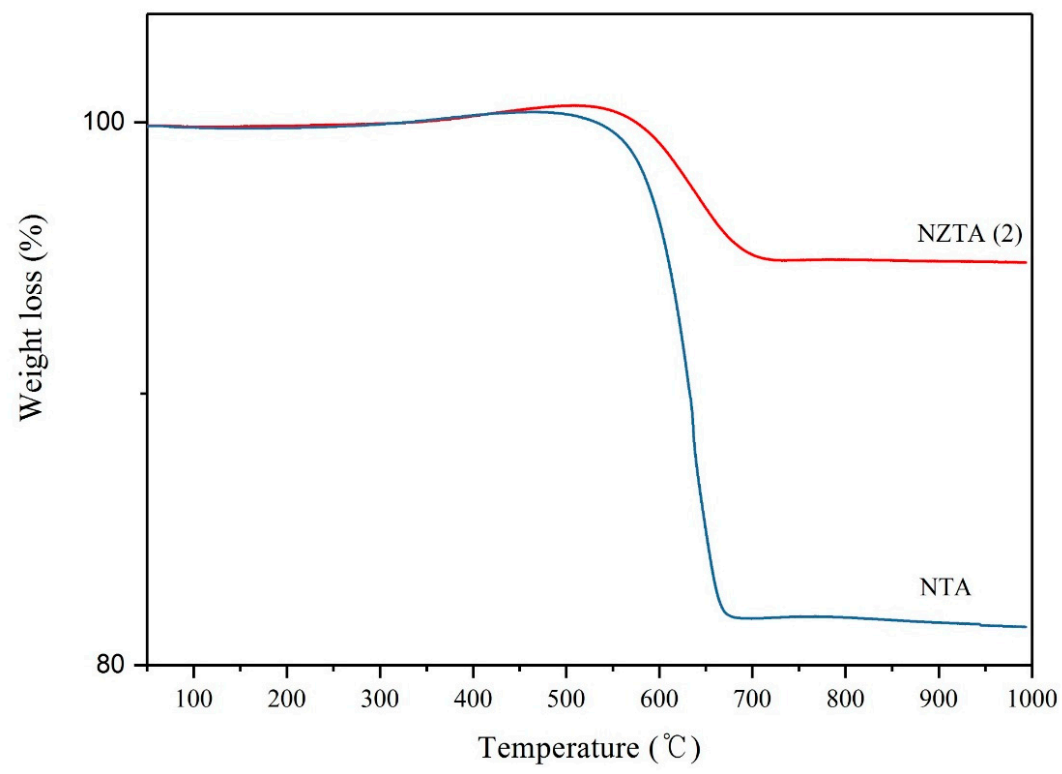

Figure 11. The TGA profiles of the spent catalysts (NATA (2) and NTA) reacted for $50 \mathrm{~h}$ in the DMR.

It is reported that beside catalytic deactivation by the coke formation there is another pathway when using $\mathrm{Ni} / \mathrm{TiO}_{2}$ in $\mathrm{DRM}$. In fact, the catalyst deactivation could also occur as a result of migration of the $\mathrm{TiO}_{x}$ to the surface of nickel sites. This site blockage could drastically cause catalyst deactivation $[21,34]$. In this research it was found that the $\mathrm{Ni} / \mathrm{ZrTiAlO}_{x}$ catalyst with low $\mathrm{Zr} / \mathrm{Ti}$ ratio elucidated the enhanced catalytic performance with the sufficient durability in DRM.

Figure 12 illustrates the influence of temperature and GHSV on $\mathrm{CH}_{4}$ conversion and syngas ratio in atmospheric pressure with the feed molar ratio of $\mathrm{CH}_{4}: \mathrm{CO}_{2}=1$ over NZTA (2) catalyst. This result confirms that the reaction conditions are important parameters to adjust the syngas ratios in the DRM. It is understood that the $\mathrm{H}_{2} / \mathrm{CO}$ ratio could be adjusted via the reaction conditions in the DRM over 
NZTA (2) catalyst and eventually it can be applied for the production of the synthetic fuels such as dimethyl ether (DME), methanol, gas-to-liquid (GTL) and other value-added chemicals.

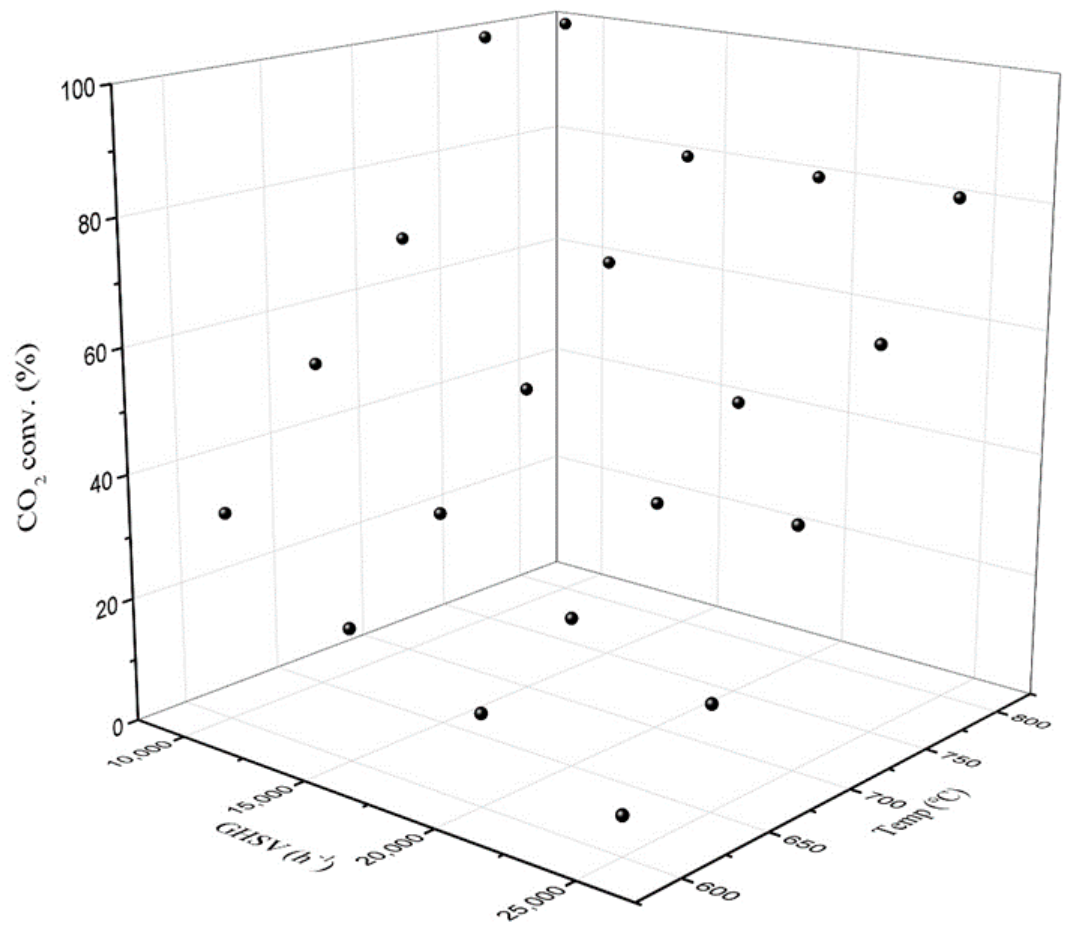

(a)

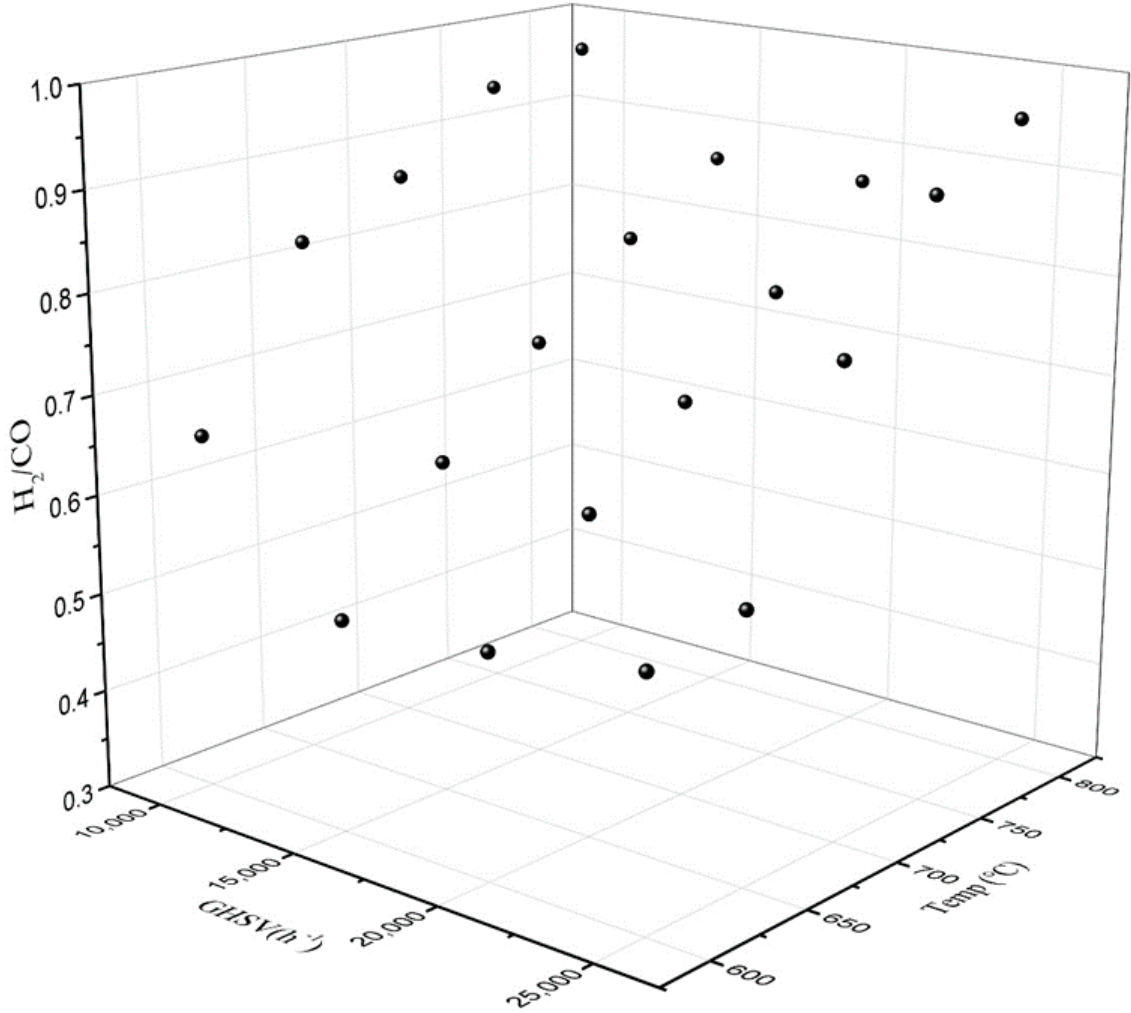

(b)

Figure 12. The effect of temperature and GHSV on (a) the $\mathrm{CH}_{4}$ conversion and (b) $\mathrm{H}_{2} / \mathrm{CO}$ ratio in the DRM at the pressure of 1 bar and feed molar ratio of $\mathrm{CH}_{4}: \mathrm{CO}_{2}=1$ over NZTA (2) catalyst. 


\subsection{The Role of $\mathrm{ZrO}_{2}$ and $\mathrm{TiO}_{2}$ over $\mathrm{Ni} / \mathrm{ZrO}_{2}-\mathrm{Al}_{2} \mathrm{O}_{3}-\mathrm{TiO}_{2}$ Catalyst in the Dry Reforming of Methane}

To obtain a commercial catalyst, various criteria are essential as owning high catalytic performance with durable stability, the low-pressure drop in the process, excellent heat transfer, high mechanical strength, robust formulation, and specifically high resistance to coke deposition. Schematic view for the reaction mechanism for the DRM has been illustrated in Figure 13. General reaction mechanism of catalytic DRM is described as follows:

$$
\begin{aligned}
\mathrm{CH}_{4} & \rightarrow \mathrm{CH}_{3}+\mathrm{H} \\
\mathrm{CO}_{2}+\mathrm{H} & \rightarrow \mathrm{CO}+\mathrm{OH} \\
\mathrm{CH}_{4}+\mathrm{O} & \rightarrow \mathrm{CH}_{3}+\mathrm{OH} \\
\mathrm{CH}_{3} & \rightarrow \mathrm{CH}_{2}+\mathrm{H} \\
\mathrm{CH}_{2} & \rightarrow \mathrm{CH}+\mathrm{H} \\
\mathrm{CH} x & \rightarrow \mathrm{C}+x \mathrm{H} \\
\mathrm{CH} x+\mathrm{O} & \rightarrow \mathrm{CO}+x \mathrm{H} \\
\mathrm{CH} x+\mathrm{CO}_{2} & \rightarrow 2 \mathrm{CO}+x \mathrm{H} \\
2 \mathrm{H} & \rightarrow \mathrm{H}_{2} \\
2 \mathrm{OH} & \rightarrow \mathrm{H}_{2} \mathrm{O}
\end{aligned}
$$

The DRM follows dehydrogenation of $\mathrm{CH}_{4}$ after adsorption on the Ni particles to initiate the carbon and hydrogen needed. As a next step the dissociative adsorption of $\mathrm{CO}_{2}$ and $\mathrm{H}_{2}$ continues by the $\mathrm{CO}_{2}$ reduction into $\mathrm{CO}$. It must be noticed that $\mathrm{CO}_{2}$ is also prone to be converted to $\mathrm{CO}$ through the reverse water-gas shift reaction (RWGS). Moreover, the small portions of syngas can also be produced via the reaction of $\mathrm{CH}_{\mathrm{x}}$ with internal generated steam.

In this research the addition of zirconia to the support inhibited the coke formation. A bi-functional mechanism is suggested as $\mathrm{ZrO}_{2}$ in the support can significantly enhance the dissociation of $\mathrm{CO}_{2}$ through the generation of the oxygen intermediates in the catalyst surface. The coke can be gasified by the immense effect of $\mathrm{ZrO}_{2}$. Furthermore, the methane activation can take place by the surface reaction with adsorbed oxygen atoms.

It was recognized that $\mathrm{TiO}_{2}$ would have reduced the carbon nucleation on the $\mathrm{Ni}$ active sites, which consequently decreased the binding energies between carbon atoms and $\mathrm{Ni}$ particles on the catalyst surface. Based on our results the resistance for the coke formation in the $\mathrm{Ni} / \mathrm{ZrO}_{2}-\mathrm{Al}_{2} \mathrm{O}_{3}-\mathrm{TiO}_{2}$ catalyst has been improved, which can confirm this assumption. It is imperative that the catalyst can oxidize the surface carbon efficiently without $\mathrm{C}-\mathrm{C}$ bond formation. 


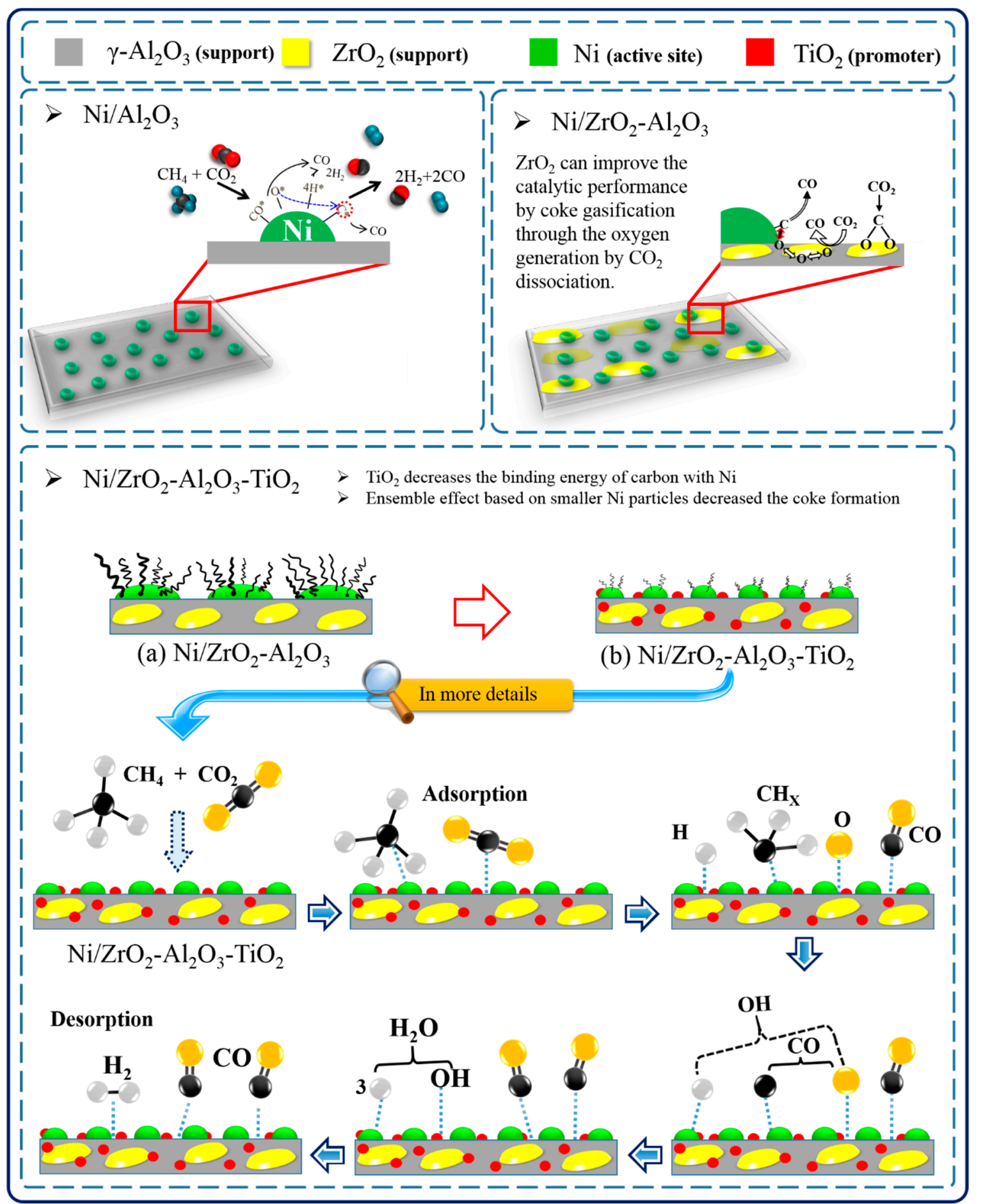

Figure 13. Schematic sketch for mechanism and the role of $\mathrm{ZrO}_{2}$ and $\mathrm{TiO}_{2}$ in the $\mathrm{Ni} / \mathrm{ZrO} \mathrm{O}_{2}-\mathrm{Al}_{2} \mathrm{O}_{3}-\mathrm{TiO}_{2}$ catalyst for the dry reforming of methane.

\section{Experiment}

\subsection{Preparation of Supports}

The $\mathrm{ZrTiAlO}_{x}$ supports were synthesized via the modified Pechini sol-gel method. $\mathrm{Al}\left(\mathrm{NO}_{3}\right)_{3} \cdot 9 \mathrm{H}_{2} \mathrm{O}$ (98\%, Samchun Chem., Gangnam-gu, Republic of Korea), titanium tetraisopropoxide (97\%, Alfa Aesar, Ward Hill, MA, USA), and $\mathrm{Zr}\left(\mathrm{NO}_{3}\right)_{4}$ (35 wt.\% diluted in the $\mathrm{HNO}_{3}$, Sigma-Aldrich, St. Louis, MI, USA) were purchased to be used as metal precursors for the synthesis of support. Metal nitrates 
and citric acid (CA) were mixed. Then, ethylene glycol (EG) was added gradually to this solution $(\mathrm{CA} / \mathrm{EG}=2.4)$. The $\mathrm{pH}$ of solution was set to 7 using $\mathrm{NH}_{4} \mathrm{OH}$. Next, this mixture was dried in a vacuum rotary evaporator until a viscous yellow residual was obtained. It was eventually dried at $110{ }^{\circ} \mathrm{C}$ overnight and calcined at $800{ }^{\circ} \mathrm{C}$ under airflow for $6 \mathrm{~h}$. The molar ratio of $\mathrm{Al} /(\mathrm{Zr}+\mathrm{Ti})$ was adjusted to 3:1. Nickel (15 wt.\%) was doped to the calcined $\mathrm{ZrTiAlO}_{x}$ supports by an impregnation method. The molar ratio of $\mathrm{Zr} / \mathrm{Ti}$ in the support was selected 1, 2, and 4 and known as NZTA (1), NZTA (2), NZTA (4) respectively. For the comparative study, two different supports, $\mathrm{ZrO}_{2}-\mathrm{Al}_{2} \mathrm{O}_{3}$, and $\mathrm{TiO}_{2}-\mathrm{Al}_{2} \mathrm{O}_{3}$ were synthesized. Simultaneously $\mathrm{Ni} / \mathrm{ZrO}_{2}-\mathrm{Al}_{2} \mathrm{O}_{3}$, and $\mathrm{Ni} / \mathrm{TiO}_{2}-\mathrm{Al}_{2} \mathrm{O}_{3}$ were known as NZA, and NTA, respectively.

\subsection{Characterization of Catalysts}

The synthesized catalysts (fresh and used) were characterized by various analysis such as XRD, $\mathrm{N}_{2}$ physisorption, temperature-programmed techniques $\left(\mathrm{H}_{2}-\mathrm{TPR}\right.$, TPSR, and $\mathrm{CH}_{4}$-TPD), in situ DRIFT, and thermos-gravimetric analysis (TGA).

Crystal structure was studied using an XRD-6000 diffractometer (Shimadzu Co., Kyoto, Japan) operated with a $\mathrm{Cu}-\mathrm{K} \alpha$ radiation of $1.5406 \mathrm{~nm}$ at $40 \mathrm{kV}$ and $30 \mathrm{~mA}$. The scanning range was 10 to $100^{\circ}$ with the step size of $0.04^{\circ} / \mathrm{s}$. The average crystallite sizes of nickel oxide were estimated with the Scherrer equation [35].

$\mathrm{N}_{2}$-physisoption was carried out to measure specific surface area, pore diameter, and volume. For this purpose, a $\mathrm{N}_{2}$-physisorption analyzer (Moonsorp-I, KIST, Seoul, Republic of Korea) was used with nitrogen adsorption at $-196{ }^{\circ} \mathrm{C}$. Before starting the analysis, the degassing of catalysts was performed at $200{ }^{\circ} \mathrm{C}$ under vacuum condition $(0.01 \mathrm{bar})$ for $3 \mathrm{~h}$ to remove physically adsorbed impurities and moisture [36].

Autochem 2910 (Micromeritics Co., Dr. Norcross, GA 30093-2901, USA) was used to carry out the temperature-programmed techniques. It was equipped with a Thermal Conductivity Detector (TCD). The reducibility of all synthesized catalysts was investigated using temperature-programmed reduction (TPR) of hydrogen. Synthe sized catalysts were loaded in a U-shape quartz tube with gas stream of $5 \% \mathrm{H}_{2} / \mathrm{Ar}$ flow $(50 \mathrm{~mL} / \mathrm{min})$ heated from room temperature up to $1000^{\circ} \mathrm{C}\left(10{ }^{\circ} \mathrm{C} / \mathrm{min}\right)$ [37].

As an in situ reaction analysis and in order to study the carbon intermediate components with their influences in the DRM, temperature-programmed surface reactions (TPSR) were performed on the synthesized catalysts. It was coupled with a Mass Spectrometer (MS) and Quadstar 320 (ThermoStar GSD 220, Pfeiffer Vacuum, Asslar, Germany). Initially all the catalysts were reduced with $5 \% \mathrm{H}_{2} / \mathrm{Ar}$ stream at $800{ }^{\circ} \mathrm{C}$ for $2 \mathrm{~h}$. The reduced catalysts were tested using mixed gas $\left(\mathrm{CO}_{2}, \mathrm{CH}_{4}\right.$, and $\left.\mathrm{He}\right)$ with flow rate of $50 \mathrm{~mL} / \mathrm{min}$ and $\mathrm{CH}_{4}(30 \mathrm{~mL} / \mathrm{min})$. The samples were heated up to $1,000{ }^{\circ} \mathrm{C}$ with heating rate of $10{ }^{\circ} \mathrm{C} / \mathrm{min}$. The desorbing components were constantly screened by their characteristic mass fragments (m/e): $2\left(\mathrm{H}_{2}\right), 18\left(\mathrm{H}_{2} \mathrm{O}\right), 4(\mathrm{He}), 28\left({ }^{12} \mathrm{CO}\right), 29\left({ }^{13} \mathrm{CO}\right), 44\left({ }^{12} \mathrm{CO}_{2}\right), 45\left({ }^{13} \mathrm{CO}_{2}\right), 15\left({ }^{12} \mathrm{CH}_{4}\right)$, and $17\left({ }^{13} \mathrm{CH}_{4}\right)[38]$.

Used catalysts were initially treated at $400{ }^{\circ} \mathrm{C}$ for $1 \mathrm{~h}$ with He stream, then, temperatureprogrammed hydrogenation (TPH) was performed using $5 \% \mathrm{H}_{2} / \mathrm{Ar}$ (flow rate of $50 \mathrm{~mL} / \mathrm{min}$ ) and heating up to $1000{ }^{\circ} \mathrm{C}$ with a ramping rate of $10{ }^{\circ} \mathrm{C} / \mathrm{min}$ [37].

Thermogravimetric analysis (TGA) was used for measuring the coke formation in the used catalysts after the DRM with SDT Q 600 (TA instruments, New Castle, DE, USA). The TGA analysis was carried out from $\mathrm{T}=25-1000^{\circ} \mathrm{C}$ under air atmosphere and a ramping temperature of $10^{\circ} \mathrm{C} / \mathrm{min}$ [39].

A FT-IR Spectrometer (Nicolet iS50, Thermo Fisher Scientific Inc., Waltham, MA, USA) with a diffuse reflectance cell was used for the in situ DRIFTS (Diffuse Reflectance Infrared Fourier Transform Spectroscopy) analysis. All synthesized catalysts prior to the analysis were reduced with $5 \% \mathrm{H}_{2} / \mathrm{Ar}$ stream at $80{ }^{\circ} \mathrm{C}$ for $2 \mathrm{~h}$. Then, the setup was purged by He to sweep out any impurities. Initially the background spectra for the loaded catalyst was taken at certain temperature, then mixed gas including $\mathrm{CO}_{2}, \mathrm{CH}_{4}$, and $\mathrm{He}$ with flow rate of $40 \mathrm{~mL} / \mathrm{min}$ was inserted to the system for $0.5 \mathrm{~h}$ [31]. The spectra 
were recorded with $5 \mathrm{~min}$ intervals, and subsequently the background was subtracted. In this research we used OMNIC-FTIR software.

\subsection{Catalytic Performance Test under the Dry Reforming of Methane}

The DRM was performed in a fixed-bed down-flow tubular reactor (O.D. $=12.7 \mathrm{~mm})$. To activate the catalyst, $250 \mathrm{mg}$ of the synthesized catalyst was in situ reduced with $5 \% \mathrm{H}_{2} / \mathrm{Ar}$ stream at $800{ }^{\circ} \mathrm{C}$ for $2 \mathrm{~h}$. The feed molar ratio was $\mathrm{CH}_{4} / \mathrm{CO}_{2}=1$ and the DRM reaction was carried out at $600{ }^{\circ} \mathrm{C}, 1 \mathrm{bar}$, with the GHSV of $45,000 \mathrm{~h}^{-1}$. $\mathrm{N}_{2}$ was used as the internal standard gas. The products were analyzed using online gas chromatography (HP Aglient GC 7890A, Agilent Technologies, Santa Clara, CA, USA). The GC was equipped with a carbosphere $60 / 80$ packed column. Table 2 lists further details on the analytical conditions.

Table 2. Analytical conditions by online G.

\begin{tabular}{cc}
\hline Parameters & Conditions \\
\hline Packing type & Carbosphere packed column $60 / 80$ meshes $2.5 \mathrm{~m} \times 2.16 \mathrm{~mm}$ I.D. \\
Injector temp. & $200^{\circ} \mathrm{C}$ \\
Oven temp. & $120^{\circ} \mathrm{C}$ \\
TCD temp. & $250{ }^{\circ} \mathrm{C}$ \\
Ar flow rate (carrier gas) & $20 \mathrm{~mL} / \mathrm{min}$ \\
recording intervals & $\sim 20 \mathrm{~min}$ \\
\hline
\end{tabular}

The feed conversions for carbon dioxide, and methane were calculated by the following Equations (11) and (12).

$$
\begin{aligned}
& \mathrm{CO}_{2} \text { conv. }(\%)=\frac{\mathrm{CO}_{2, I N}-\mathrm{CO}_{2, \mathrm{OUT}}}{\mathrm{CO}_{2, \mathrm{IN}}} \times 100 \\
& \mathrm{CH}_{4} \text { conv. }(\%)=\frac{\mathrm{CH}_{4, \mathrm{IN}}-\mathrm{CH}_{4, \mathrm{OUT}}}{\mathrm{CH}_{4, \mathrm{IN}}} \times 100
\end{aligned}
$$

\section{Conclusions}

The Ni-based catalysts $(15 \% \mathrm{Ni} / \mathrm{ZrTiAlO})_{x}$ ) with different $\mathrm{Zr} / \mathrm{Ti}$ ratios were successfully synthesized by the modified Pechini sol-gel and an impregnation method. The synthesized catalysts were characterized and the catalytic performance tests for DRM were carried out at low temperature. All synthesized $\mathrm{Ni} / \mathrm{ZrTiAlO}$ catalysts showed similar patters based on the XRD results. It is found that the addition of $\mathrm{TiO}_{2}$ could boost the coke resistance in DRM; however, there is a drawback that migration of $\mathrm{TiO}_{2}$ to the Ni sites would deactivate the catalysts as well. Therefore, to overcome this issue, in this research the addition of $\mathrm{ZrO}_{2}$ in the support was studied. $\mathrm{Ni} / \mathrm{ZrTiAlO}{ }_{x}$ catalysts with various $\mathrm{Zr} / \mathrm{Ti}$ ratios were synthesized. The catalytic performance and durability mainly relies on the $\mathrm{Zr} / \mathrm{Ti}$ ratios in the catalysts. It was concluded that ratio of $\mathrm{Zr} / \mathrm{Ti}=2$ exhibited better coke inhibition features in DRM compared to the other synthesized catalysts under low temperature for $50 \mathrm{~h}$. Higher ratios of $\mathrm{Zr} / \mathrm{Ti}$ would lead to higher catalyst activity but at the moment the catalysts were also rapidly deactivated. Based on the results of in situ DRIFTS and TPSR analysis, it was found that $\mathrm{Ni} / \mathrm{ZrTiAlO}{ }_{x}$ catalyst $15 \% \mathrm{Ni}$ contents and $\mathrm{Zr} / \mathrm{Ti}=2$ showed higher catalytic stability and sufficient activity. In fact, the introduction of $\mathrm{Ti}$ to the $\mathrm{ZrO}_{2}-\mathrm{Al}_{2} \mathrm{O}_{3}$ provides the oxygen vacancies in the ternary metal oxide composite. It was suggested that the $\mathrm{Ni} / \mathrm{ZrTiAlO}{ }_{x}$ catalyst with $\mathrm{Zr} / \mathrm{Ti}=2$ showed high catalytic performance with the significant catalyst stability towards coke deposition.

Author Contributions: Conceptualization, S.A.S. and A.A.E.; methodology, S.A.S.; software, S.A.S. and A.A.E.; formal analysis, S.A.S. and Y.S.N.; investigation, S.A.S. and A.A.E.; resources, D.J.M.; data curation, S.A.S. and N.G.S.; writing original draft preparation, S.A.S.; writing review and editing, S.A.E., A.A.E., Y.S.N., H.-t.S., H.D.K. and N.G.S.; visualization, A.A.E. and N.G.S.; supervision, D.J.M.; project administration, D.J.M.; funding acquisition, D.J.M.; All authors have read and agreed to the published version of the manuscript. 
Funding: This work was supported and funded by the Korea Institute of Science and Technology (Project No. 2E30570).

Acknowledgments: The authors gratefully acknowledge all of their co-workers for their valuable research contributions.

Conflicts of Interest: The authors declare no conflict of interest.

\section{References}

1. Rostrup-Nielsen, J.R. New aspects of syngas production and use. Catal. Today 2000, 63, 159-164. [CrossRef]

2. Sharifi, M.; Haghighi, M.; Eslami, A.A.; Rahmani, F.; Rahemi, N. Synthesis and Characterization of $\mathrm{Ni}-\mathrm{Cu} / \mathrm{Al}_{2} \mathrm{O}_{3}-\mathrm{ZrO}_{2}$ Nanocatalyst via Sequential Impregnation and Sol-Gel Methods Used in $\mathrm{CH}_{4} / \mathrm{CO}_{2}$ Conversion to Syngas. Pet. Res. 2016, 25, 142-157.

3. Eslami, A.A.; Haghighi, M.; Rahemi, N.; Laheghi, S.N. Sol-Gel Synthesis and Characterization of $\mathrm{Ni}_{2} / \mathrm{Al}_{2} \mathrm{O}_{3}$ Nanocatalysts Doped with Co and Cu. In AIP Conference Proceedings; American Institute of Physics: College Park, MD, USA, 2011; Volume 1315, pp. 1297-1302.

4. Baltrusaitis, J.; Luyben, W.L. Methane Conversion to Syngas for Gas-to-Liquids (GTL): Is Sustainable $\mathrm{CO}_{2}$ Reuse via Dry Methane Reforming (DMR) Cost Competitive with SMR and ATR Processes? ACS Sustain. Chem. Eng. 2015, 3, 2100-2111. [CrossRef]

5. Gangadharan, P.; Kanchi, K.C.; Lou, H.H. Evaluation of the economic and environmental impact of combining dry reforming with steam reforming of methane. Chem. Eng. Res. Des. 2012, 90, 1956-1968. [CrossRef]

6. Hong, G.H.; Shin, D.; Moon, D.J. Development of fixed bed reactor for applications in GTL-FPSO: The effect of dilution material for control of reaction heat. Catal. Today 2020, in press. [CrossRef]

7. Kim, H.D.; Song, H.-T.; Fazeli, A.; Eslami, A.A.; Noh, Y.S.; Saeidabad, N.G.; Lee, K.-Y.; Moon, D.J. CO/CO 2 hydrogenation for the production of lighter hydrocarbons over SAPO-34 modified hybrid FTS catalysts. Catal. Today 2020, in press. [CrossRef]

8. Bepari, S.; Kuila, D. Steam reforming of methanol, ethanol and glycerol over nickel-based catalysts-A review. Int. J. Hydrog. Energy 2020, 45, 18090-18113. [CrossRef]

9. Saeidabad, N.G.; Noh, Y.S.; Eslami, A.A.; Song, H.-T.; Kim, H.D.; Fazeli, A.; Moon, D.J. A Review on Catalysts Development for Steam Reforming of Biodiesel Derived Glycerol; Promoters and Supports. Catalysts 2020, 10, 910. [CrossRef]

10. Zhu, Y.-A.; Chen, D.; Zhou, X.-G.; Yuan, W.-K. DFT studies of dry reforming of methane on Ni catalyst. Catal. Today 2009, 148, 260-267. [CrossRef]

11. Yusuf, M.; Farooqi, A.S.; Keong, L.K.; Hellgardt, K.; Abdullah, B. Contemporary trends in composite Ni-based catalysts for $\mathrm{CO}_{2}$ reforming of methane. Chem. Eng. Sci. 2020, 229, 116072. [CrossRef]

12. Alipour, Z.; Rezaei, M.; Meshkani, F. Effect of alkaline earth promoters (MgO, $\mathrm{CaO}$, and $\mathrm{BaO})$ on the activity and coke formation of $\mathrm{Ni}$ catalysts supported on nanocrystalline $\mathrm{Al}_{2} \mathrm{O}_{3}$ in dry reforming of methane. J. Ind. Eng. Chem. 2014, 20, 2858-2863. [CrossRef]

13. Barroso-Quiroga, M.M.; Castro-Luna, A.E. Catalytic activity and effect of modifiers on Ni-based catalysts for the dry reforming of methane. Int. J. Hydrog. Energy 2010, 35, 6052-6056. [CrossRef]

14. Xu, B.-Q.; Wei, J.-M.; Yu, Y.-T.; Li, J.-L.; Zhu, Q.-M. Carbon Dioxide Reforming of Methane Over Nanocomposite $\mathrm{Ni} / \mathrm{ZrO}_{2}$ Catalysts. Top. Catal. 2003, 22, 77-85. [CrossRef]

15. Sánchez-Sánchez, M.C.; Navarro, R.M.; Fierro, J.L.G. Ethanol steam reforming over Ni/MxOy- $\mathrm{Al}_{2} \mathrm{O}_{3}(\mathrm{M}=\mathrm{Ce}$, $\mathrm{La}, \mathrm{Zr}$ and $\mathrm{Mg}$ ) catalysts: Influence of support on the hydrogen production. Int. J. Hydrog. Energy 2007, 32, 1462-1471. [CrossRef]

16. Brungs, A.J.; York, A.P.E.; Claridge, J.B.; Márquez-Alvarez, C.; Green, M.L.H. Dry reforming of methane to synthesis gas over supported molybdenum carbide catalysts. Catal. Lett. 2000, 70, 117-122. [CrossRef]

17. Guo, J.; Hou, Z.; Gao, J.; Zheng, X. DRIFTS Study on Adsorption and Activation of $\mathrm{CH}_{4}$ and $\mathrm{CO}_{2}$ over $\mathrm{Ni} / \mathrm{SiO}_{2}$ Catalyst with Various Ni Particle Sizes. Chin. J. Catal. 2007, 28, 22-26. [CrossRef]

18. Awadallah, A.E.; Mostafa, M.S.; Aboul-Enein, A.A.; Hanafi, S.A. Hydrogen production via methane decomposition over $\mathrm{Al}_{2} \mathrm{O}_{3}-\mathrm{TiO}_{2}$ binary oxides supported Ni catalysts: Effect of Ti content on the catalytic efficiency. Fuel 2014, 129, 68-77. [CrossRef]

19. Xu, Z.; Li, Y.; Zhang, J.; Chang, L.; Zhou, R.; Duan, Z. Bound-state Ni species-A superior form in Ni-based catalyst for $\mathrm{CH}_{4} / \mathrm{CO}_{2}$ reforming. Appl. Catal. A Gen. 2001, 210, 45-53. [CrossRef] 
20. Dong, W.-S.; Roh, H.-S.; Jun, K.-W.; Park, S.-E.; Oh, Y.-S. Methane reforming over Ni/Ce-ZrO 2 catalysts: Effect of nickel content. Appl. Catal. A Gen. 2002, 226, 63-72. [CrossRef]

21. Bradford, M.C.J.; Vannice, M.A. Catalytic reforming of methane with carbon dioxide over nickel catalysts I. Catalyst characterization and activity. Appl. Catal. A Gen. 1996, 142, 73-96. [CrossRef]

22. Yan, Q.G.; Weng, W.Z.; Wan, H.L.; Toghiani, H.; Toghiani, R.K.; Pittman, C.U. Activation of methane to syngas over a $\mathrm{Ni} / \mathrm{TiO}_{2}$ catalyst. Appl. Catal. A Gen. 2003, 239, 43-58. [CrossRef]

23. Chauke, H.R.; Murovhi, P.; Ngoepe, P.E.; de Leeuw, N.H.; Grau-Crespo, R. Electronic Structure and Redox Properties of the Ti-Doped Zirconia (111) Surface. J. Phys. Chem. C 2010, 114, 15403-15409. [CrossRef]

24. Gallino, F.; di Valentin, C.; Pacchioni, G. Band gap engineering of bulk $\mathrm{ZrO}_{2}$ by Ti doping. Phys. Chem. Chem. Phys. 2011, 13, 17667-17675. [CrossRef] [PubMed]

25. Zhou, W.; Liu, K.; Fu, H.; Pan, K.; Zhang, L.; Wang, L.; Sun, C.C. Multi-modal mesoporous TiO(2)-ZrO(2) composites with high photocatalytic activity and hydrophilicity. Nanotechnology 2008, 19, 035610. [CrossRef]

26. Shin, S.A.; Noh, Y.S.; Hong, G.H.; Park, J.I.; Song, H.T.; Lee, K.-Y.; Moon, D.J. Dry reforming of methane over $\mathrm{Ni} / \mathrm{ZrO}_{2}-\mathrm{Al}_{2} \mathrm{O}_{3}$ catalysts: Effect of preparation methods. J. Taiwan Inst. Chem. Eng. 2018, 90, 25-32. [CrossRef]

27. Gonçalves, A.A.S.; Faustino, P.B.; Assaf, J.M.; Jaroniec, M. One-Pot Synthesis of Mesoporous Ni-Ti-Al Ternary Oxides: Highly Active and Selective Catalysts for Steam Reforming of Ethanol. ACS Appl. Mater. Interfaces 2017, 9, 6079-6092. [CrossRef]

28. Kim, S.S.; Lee, S.M.; Won, J.M.; Yang, H.J.; Hong, S.C. Effect of Ce/Ti ratio on the catalytic activity and stability of $\mathrm{Ni} / \mathrm{CeO}_{2}-\mathrm{TiO}_{2}$ catalyst for dry reforming of methane. Chem. Eng. J. 2015, 280, 433-440. [CrossRef]

29. Damyanova, S.; Spojakina, A.; Jiratova, K. Effect of mixed titania-alumina supports on the phase composition of $\mathrm{NiMo} / \mathrm{TiO}_{2} \mathrm{Al}_{2} \mathrm{O}_{3}$ catalysts. Appl. Catal. A Gen. 1995, 125, 257-269. [CrossRef]

30. Bitter, J.H.; Seshan, K.; Lercher, J.A. Deactivation and Coke Accumulation during $\mathrm{CO}_{2} / \mathrm{CH}_{4}$ Reforming over Pt Catalysts. J. Catal. 1999, 183, 336-343. [CrossRef]

31. Das, S.; Ashok, J.; Bian, Z.; Dewangan, N.; Wai, M.H.; Du, Y.; Borgna, A.; Hidajat, K.; Kawi, S. Silica-Ceria sandwiched Ni core-shell catalyst for low temperature dry reforming of biogas: Coke resistance and mechanistic insights. Appl. Catal. B-Environ. 2018, 230, 220-236. [CrossRef]

32. Tomishige, K.; Chen, Y.-G.; Fujimoto, K. Studies on Carbon Deposition in $\mathrm{CO}_{2}$ Reforming of $\mathrm{CH}_{4}$ over Nickel-Magnesia Solid Solution Catalysts. J. Catal. 1999, 181, 91-103. [CrossRef]

33. Rezaei, M.; Alavi, S.M.; Sahebdelfar, S.; Yan, Z.-F. Syngas Production by Methane Reforming with Carbon Dioxide on Noble Metal Catalysts. J. Nat. Gas Chem. 2006, 15, 327-334. [CrossRef]

34. Takatani, S.; Chung, Y.-W. Strong metal-support interaction in $\mathrm{NiTiO}_{2}$ : Auger and vibrational spectroscopy evidence for the segregation of TiOx $(x \approx-1)$ on $\mathrm{Ni}$ and its effects on CO chemisorption. J. Catal. 1984, 90, 75-83. [CrossRef]

35. Monshi, A.; Foroughi, M.R.; Monshi, M.R. Modified Scherrer equation to estimate more accurately nano-crystallite size using XRD. World J. Nano Sci. Eng. 2012, 2, 154-160. [CrossRef]

36. Yang, E.H.; Noh, Y.S.; Lim, S.S.; Ahn, B.S.; Moon, D.J. The Effect of Fe in Perovskite Catalysts for Steam $\mathrm{CO}_{2}$ Reforming of Methane. J. Nanosci. Nanotechnol. 2016, 16, 1938-1941. [CrossRef]

37. Noh, Y.S.; Lee, K.Y.; Moon, D.J. Hydrogen production by steam reforming of methane over nickel based structured catalysts supported on calcium aluminate modified SiC. Int. J. Hydrog. Energy. 2019, 44, 21010-21019. [CrossRef]

38. Wang, C.Z.; Sun, N.N.; Wei, W.; Zhao, Y.X. Carbon intermediates during $\mathrm{CO}_{2}$ reforming of methane over $\mathrm{Ni}-\mathrm{CaO}-\mathrm{ZrO}_{2}$ catalysts: A temperature-programmed surface reaction study. Int. J. Hydrog. Energy 2016, 41, 19014-19024. [CrossRef]

39. Yang, E.H.; Noh, Y.S.; Hong, G.H.; Moon, D.J. Combined steam and $\mathrm{CO}_{2}$ reforming of methane over La1-xSrxNiO3 perovskite oxides. Catal. Today 2018, 299, 242-250. [CrossRef]

Publisher's Note: MDPI stays neutral with regard to jurisdictional claims in published maps and institutional affiliations. 